\title{
POUSTAVLJENJE HRVATSKOG PRAVNOG PORETKA
}

Izv. prof. dr. sc. Luka Burazin*

Izv. prof. dr. sc. Đorte Gardašević**

Doc. dr. sc. Mario Krešic ***
UDK: 342.413.01(497.5)

340.131:342.4(497.5)

$340.132 .6(497.5)$

DOI: 10.3935/zpfz.71.2.04

Pregledni znanstveni rad

Primljeno: travanj 2021.

U radu se opisuje trenutačni stadij poustavljenja hrvatskog pravnog poretka primjenom Guastinijeva teorijskog modela poustavljenja pravnog poretka, koji se sastoji od tri nužna uvjeta i pet aspekata poustavljenja pravnih poredaka. U prvome se dijelu rada utvrđuje ispunjenost nužnih uvjeta poustavljenja hrvatskog pravnog poretka (dug, krut i sudski zajamčen ustav). $U$ drugome dijelu rada utvrduju se indikacije postojanja pojedinih aspekata poustavljenja hrvatskog pravnog poretka. Najprije se utvrduje prisutnost shvaćanja o obvezujućoj snazi ustavnih normi, tj., preciznije, njihova sposobnost da učine nevaljanim zakone nespojive s Ustavom RH. Zatim se utvrđuje prisutnost korištenja tehnike nadtumačenja ustava u praksi Ustavnog suda Republike Hrvatske. Nadalje, utvrduje se primjenjuju li sudci hrvatskih redovnih (ne-ustavnih) sudova ustavne norme neposredno, tj. odlučuju li u konkretnim sporovima neposredno na temelju ustavnih normi. Zatim se utvrduje korištenje tehnike prilagođujućeg tumačenja zakona u praksi Ustavnog suda RH. Konačno, utvrduje se utjecaj Ustava RH na političke odnose u Republici Hrvatskoj.

Ključne riječi: poustavljenje, pravni poredak, prilagodujuće tumačenje zakona, nadtumačenje ustava, neposredna primjena ustavnih normi

* Dr. sc. Luka Burazin, izvanredni profesor Pravnog fakulteta Sveučilišta u Zagrebu, Trg Republike Hrvatske 14, 10000 Zagreb; lburazin@pravo.hr;

https://orcid.org/0000-0002-2437-8871

** Dr. sc. Đorđe Gardašević, izvanredni profesor Pravnog fakulteta Sveučilišta u Zagrebu, Trg Republike Hrvatske 14, 10000 Zagreb; dorde.gardasevic@pravo.hr; https://orcid.org/0000-0002-2103-6139

**** Dr. sc. Mario Krešić, docent Pravnog fakulteta Sveučilišta u Zagrebu, Trg Republike Hrvatske 14, 10000 Zagreb; mario.kresic@pravo.hr, mariokresic3@gmail.com; https://orcid.org/0000-0002-0014-4157 


\section{UVOD****}

Prema R. Guastiniju poustavljenje je "proces preobrazbe pravnog poretka, čijim okončanjem dotični poredak biva potpuno 'natopljen' ustavnim normama”, a "[p]oustavljen pravni poredak odlikuje se izrazito prožimajućim, nametljivim i preplavljujućim ustavom"1 sposobnim uvjetovati "zakonodavstvo, sudsku praksu, doktrinarni stil, djelovanje političkih čimbenika, privatne odnose". ${ }^{2} \mathrm{U}$ poustavljenom pravnom poretku ustavom se utvrđuju ciljevi koje zakonodavac treba slijediti, a zakonodavac samo može izabrati najprikladnija sredstva za ostvarenje tih ciljeva, suci su ovlašteni i obvezni neposredno primjenjivati ustavne norme, što znači da su i odnosi među građanima uređeni ustavom, doktrina zakone tumači kao razradu ustavnih načela i vrijednosti, a političari i ustavni državni organi svoje postupke opravdavaju pozivanjem na ustav. ${ }^{3}$

Kako bi se uopće moglo govoriti o procesu poustavljenja u nekom pravnom poretku u navedenom smislu, nužno je, prema Guastiniju, da su ispunjena tri uvjeta: ustav mora biti dug, krut i sudski zajamčen. Ustav je dug ako, osim normi kojima se ustrojavaju ustavni organi, sadržava norme kojima se dodjeljuju ustavna prava, norme načela (norme s otvorenim uvjetima primjene i zatvorenim normativnim rješenjem) i programatske norme (norme s otvorenim uvjetima primjene i otvorenim normativnim rješenjem). ${ }^{4}$ Ustav je krut ako je materijalno hijerarhijski nadređen običnim zakonima, tj. ako ga se običnim zakonima ne može valjano mijenjati, ograničavati mu doseg ili ga ukinuti. ${ }^{5}$ Konačno, ustav je sudski zajamčen ako postoji sudski nadzor sukladnosti zakona ustavu. ${ }^{6}$

Pod pretpostavkom da su navedeni nužni uvjeti ispunjeni, proces poustavljenja se, prema Guastiniju, u nekom pravnom poretku može prepoznati u najmanje sljedećih pet aspekata: 1) u shvaćanju da su sve ustavne norme obvezujuće (tzv. obvezujuća snaga ustava), tj. da su sve ustavne norme (precizne norme pravila, norme načela i programatske norme) sposobne proizvoditi pravne učinke (npr. prouzročiti nevaljanost s ustavom nespojivih zakona); 2) u tome da organ koji nadzire ustavnost zakona nadtumači ustav tako da iz ustavnog

\footnotetext{
${ }^{* * * *}$ Autori zahvaljuju izv. prof. dr. sc. Frani Staničiću, doc. dr. sc. Alenu Rajku i Ustavnom sudu Republike Hrvatske na pomoći pri provedbi ovog istraživanja.

1 Guastini, R., Sintaksa prava, Naklada Breza, Zagreb, 2019., str. 185.

2 Ibid., str. 186.

$3 \quad$ Ibid., str. $186-187$.

$4 \quad$ Ibid., str. 187.

5 Ibid.

6 Ibid., str. 188.
} 
teksta izvodi prešutne, neizražene norme, prikladne za uređenje bilo kojeg aspekta društvenog i političkog života, čime sužava (ili gotovo posve ukida) prostor zakonodavne diskrecije (tzv. nadtumačenje ustava); 3) u tome da ustavne norme mogu neposredno primijeniti i redovni sudovi, čak i u interprivatnim odnosima (tzv. neposredna primjena ustavnih normi); 4) u tome da sudovi pri tumačenju zakonskih odredbi odabiru od više mogućih značenja ono koje je sukladno ustavu (tzv. prilagođujuće tumačenje zakona) i 5) u utjecaju ustava na političke odnose, putem ustavnosudskog korištenja različitih sredstva koja imaju implikacije za političke odnose (npr. ustavnosudsko rješavanje sukoba nadležnosti između državnih vlasti, nadzor ustavnosti referendumskih pitanja, odvagivanje ustavnih načela, ocjenjivanje razložnosti zakonskih razlikovanja) i putem načina na koje ustavni organi i politički čimbenici opravdavaju svoje postupke i odluke te kritiziraju tuđe (tj. kada svoja opravdanja i kritike temelje na ustavnim normama). ${ }^{7}$

Prema Guastiniju poustavljenje je stvar stupnja: poredak može biti poustavljen u većoj ili manjoj mjeri, što ovisi o tome koliko je od navedenih aspekata poustavljenja u nekom pravnom poretku prisutno, koji od njih i u kojoj su mjeri ti aspekti zastupljeni. ${ }^{8}$ Navedene uvjete i aspekte poustavljenja Guastini smatra prihvatljivom polaznom osnovom za analiziranje procesa poustavljenja u konkretnim pravnim poredcima. ${ }^{9}$

Koristeći se Guastinijevim pojmom poustavljenja i njegovim teorijskim modelom poustavljenja (koji se sastoji od 3 nužna uvjeta i 5 aspekata poustavljenja), u ovome ćemo radu analizirati proces poustavljenja u hrvatskom pravnom poretku. Cilj našeg istraživanja je opisati u čemu se očituje trenutačni stadij procesa poustavljenja hrvatskog pravnog poretka, tj. utvrditi koji su elementi poustavljenja zastupljeni u hrvatskom pravnom poretku. Pri tome polazimo od pretpostavke da je hrvatski pravni poredak već u određenoj mjeri poustavljen i da trenutačno prolazi proces poustavljenja. S obzirom na to da, koliko nam je poznato, ne postoji razrađena mjerna ljestvica poustavljenja, u radu nećemo utvrđivati stupanj poustavljenja hrvatskog pravnog poretka, nego ćemo se ograničiti na utvrđivanje indikacija postojanja pojedinih aspekata poustavljenja hrvatskog pravnog poretka navođenjem dovoljnog broja relevantnih primjera.

$7 \quad$ Vidi ibid., str. $188-208$.

8 Guastini, R., La “costituzionalizzazione” dell’ordinamento italiano, Ragion pratica, sv. 11, 1998., str. 185. O stupnjevitosti poustavljenja vidi i Chiassoni, P., Constitutionalism Out of a Positivist Mind Cast: The Garantismo Way, Res Publica, sv. 17, br. 4, 2011. str. 329.

9 Guastini, op. cit. u bilj. 8, str. 186. 
U prvome dijelu rada (2. poglavlje) utvrđivat ćemo ispunjenost nužnih uvjeta poustavljenja hrvatskog pravnog poretka koristeći se metodama utvrđivanja postojećih i primjenljivih ustavnopravnih normi, a uglavnom metodama utvrđivanja izvora prava i metodama tumačenja normativnih tekstova. U drugome dijelu rada (3. poglavlje) utvrđivat ćemo indikacije postojanja pojedinih aspekata poustavljenja hrvatskog pravnog poretka. Najprije ćemo (potpoglavlje 3.1.) utvrđivati prisutnost shvaćanja o obvezujućoj snazi ustavnih normi, tj., preciznije, njihovu sposobnost da učine nevaljanim zakone (ili zakonske norme) nespojive s Ustavom Republike Hrvatske (dalje u tekstu: Ustav RH). ${ }^{10}$ Zatim ćemo (potpoglavlje 3.2.) utvrđivati prisutnost korištenja tehnike nadtumačenja ustava u praksi Ustavnog suda Republike Hrvatske (dalje u tekstu: Ustavni sud RH). Nadalje (potpoglavlje 3.3.), utvrđivat ćemo primjenjuju li (ponekad) sudci hrvatskih redovnih sudova ustavne norme neposredno, tj. odlučuju li u konkretnim sporovima neposredno na temelju ustavnih normi. Zatim ćemo (potpoglavlje 3.4.) utvrđivati korištenje tehnike prilagođujućeg tumačenja zakona u praksi Ustavnog suda RH. Konačno (potpoglavlje 3.5.), utvrđivat ćemo utjecaj Ustava RH na političke odnose u Republici Hrvatskoj. Nalazi koje ćemo u ovome dijelu rada izložiti bit će, uglavnom, izvedeni argumentacijskom analizom ustavnosudskih odluka i odluka redovnih sudova i korištenjem argumentacijske sheme unutarnjeg i vanjskog opravdanja sudačkog rasuđivanja. ${ }^{11}$

\section{UVJETI POUSTAVLJENJA HRVATSKOG PRAVNOG PORETKA}

Pravni poredak Republike Hrvatske ispunjava sva tri nužna uvjeta poustavljenja. Ustav RH pripada vrsti tzv. dugih, krutih i sudski zajamčenih ustava.

(a) Ustav RH je tzv. dugi ustav jer uz odredbe kojima su formulirane norme o ustrojstvu i raspodjeli javnih vlasti (npr. norme izražene najvećim dijelom odredbi IV. - VI. glave Ustava: Ustrojstvo državne vlasti, Ustavni sud Republi-

10 Ustav RH, Narodne novine, br. 56/1990, 135/1997, 08/1998, 113/2000, 124/2000, 28/2001, 41/2001, 55/2001, 76/2010, 85/2010, 05/2014.

11 Osim ovakvog pravoznanstvenog istraživanja poustavljenja, usmjerenog ponajprije na utvrđivanje normativnog uređenja i načina opravdanja sudskih odluka, u literaturi se predlaže i provođenje interdisciplinarnog empirijskog istraživanja pravne svijesti sudaca, ali i ostalih ustavnih organa i građana, koje bi se usredotočilo na utvrđivanje stavova i vjerovanja sudaca, ostalih ustavnih organa i građana u pogledu važnosti i utjecaja ustava u pravnom poretku. O mogućim polaznim osnovama takvog istraživanja vidi Krešić, M., Legal consciousness and (de)constitutionalisation of the legal order, u: Mercescu, A. (ur.), Constitutional Identities in Central and Eastern Europe, Peter Lang, Berlin, 2020., str. 117 - 134. 
ke Hrvatske i Mjesna, lokalna i područna (regionalna) samouprava) sadržava odredbe kojima su formulirane norme kojima se dodjeljuju temeljne slobode i prava, norme načela ${ }^{12}$ i programatske norme. ${ }^{13}$

Norme kojima se dodjeljuju temeljne slobode i prava (tzv. povelja o pravima) formulirane su velikim dijelom odredbi III. glave Ustava "Zaštita ljudskih prava i sloboda”, primjerice, čl. 21. (pravo na život), čl. 22. (pravo na osobnu slobodu), čl. 29., st. l. (pravo na pravično suđenje), čl. 38., st. 1. (pravo na slobodu mišljenja i izražavanja misli), čl. 42. (pravo na javno okupljanje i mirni prosvjed), čl. 43., st. 1. (pravo na slobodno udruživanje), čl. 45., st. 1. (pravo glasa) i čl. 48., st. 1. (pravo vlasništva).

Norme načela izražene su, primjerice, odredbama čl. l., st. 1. (načelo demokracije i socijalne države), čl. 1., st. 2. (načelo narodnog suvereniteta), čl. 4. (načelo diobe vlasti), čl. 5. (načelo ustavnosti i zakonitosti), čl. 14. (načelo zabrane diskriminacije i jednakost svih pred zakonom), čl. 16., st. 2. (načelo razmjernosti), čl. 19., st. 1. (načelo zakonitosti upravnih akata), čl. 28. (načelo presumpcije nedužnosti), čl. 29. (načelo pravičnosti postupka), čl. 31., st. 1. (načelo nullum crimen nulla poena sine lege i načelo primjene blaže kazne) i čl. 51., st. 2. (načelo porezne jednakosti i pravednosti).

12 Norme načela su norme s otvorenim uvjetima primjene i zatvorenim normativnim rješenjem, u tom smislu da normom nije (iscrpno) određeno pod kojim pretpostavkama se ona primjenjuje, tj. nije (iscrpno) određen razred činjeničnih stanja u nazočnosti kojih nastupa posljedica određena tom normom, ali je određeno normativno rješenje, tj. određena je deontička kvalifikacija ponašanja (zabranjeno, obvezno, dopušteno). Primjerice, u ustavnoj normi o jednakosti i zabrani diskriminacije (koja se izvodi iz čl. 14. Ustava RH) nisu određena činjenična stanja u kojima može doći do diskriminacije, ali je određeno da je diskriminiranje zabranjeno. Vidi Atienza, M.; Manero, J. R., A Theory of Legal Sentences, Kluwer Academic Publishers, Dordrecht, 1998., str. 8 - 11 .

13 Programatske norme su norme koje imaju otvorene i uvjete primjene i normativna rješenja, u tom smislu da normom nije (iscrpno) određeno pod kojim pretpostavkama se ona primjenjuje, a nije određeno ni normativno rješenje. Primjerice, u ustavnoj normi o zaštiti prava i interesa državljana koji žive ili borave u inozemstvu i promicanju njihovih veza s domovinom (koja se izvodi iz čl. 10., st. 1. Ustava RH) nisu (iscrpno) određena činjenična stanja u kojima državni organi trebaju štititi prava i interese dotičnih državljana i promicati njihove veze s domovinom, a nisu deontički (kao obvezne ili dopuštene) određene ni radnje kojima bi državni organi trebali štititi prava i interese dotičnih državljana i promicati njihove veze s domovinom. Programatske su norme zapravo one norme koje nalažu ostvarenje određenog cilja (stanja stvari) u situacijama koje normom nisu iscrpno određene, pri čemu su adresati norme ovlašteni odabrati najprikladnija sredstva za ostvarenje dotičnog cilja. Vidi Atienza, Manero, op. cit. u bilj. 12, str. 11 - 12. 
Programatske su norme (u koje se često ubrajaju i norme kojima se dodjeljuju socijalna prava) izražene, primjerice, odredbama čl. 10., st. 1. (zaštita prava i interesa hrvatskih državljana koji žive ili borave u inozemstvu i promicanje njihove veze s domovinom), čl. 49., st. 3. (poticanje gospodarskog napretka i socijalnog blagostanja građana i briga za gospodarski razvitak svih krajeva Republike Hrvatske), čl. 58., st. 2. i 3. (zaštita osoba s invaliditetom i njihovo uključivanje u društveni život te zaštita hrvatskih branitelja, hrvatskih ratnih vojnih invalida, udovica, roditelja i djece poginulih hrvatskih branitelja), čl. 62., st. 1. (zaštita obitelji), čl. 63. (zaštita materinstva, djece i mladeži i stvaranje socijalnih, kulturnih, odgojnih, materijalnih i drugih uvjeta kojima se promiče ostvarivanje prava na dostojan život), čl. 64., st. 5. (skrb prema maloljetnicima bez roditelja i onima za koje se ne brinu roditelji), čl. 69., st. 2. i 3. (poticanje i pomaganje razvitka znanosti, kulture i umjetnosti i zaštita znanstvenih, kulturnih i umjetničkih dobara kao duhovne narodne vrednote) i čl. 70., st. 2. (osiguravanje uvjeta za zdrav okoliš).

(b) Prema načinu mijenjanja Ustav RH je tzv. kruti ustav. Naime, između Ustava RH i (običnih i organskih) zakona u hrvatskom pravnom poretku, osim formalne (ili strukturne) $)^{14}$, postoji i materijalna (ili supstancijalna) hijerarhija. Materijalna hijerarhija između dviju normi postoji kada je nekom normom (ili normama) određeno da se nekom drugom normom ne može trećoj normi valjano proturječiti, mijenjati je, ograničiti joj doseg ili je ukinuti. ${ }^{15}$ Materijalna hijerarhija između Ustava RH i hrvatskih (običnih i organskih) zakona uspostavljena je normama koje proizlaze iz, primjerice, odredbi čl. 5., st. 1. Ustava RH, prema kojem se zakonima može proizvesti samo norme koje su u skladu s Ustavom; čl. 129. Ustava te čl. 37., st. 1. i čl. 55., st. 1. Ustavnog zakona o Ustavnom sudu Republike Hrvatske (dalje u tekstu: UZUSRH) ${ }^{16}$, kojima se ovlašćuju redovni (ne-ustavni) sudovi da ne primijene i Ustavni sud RH da ukine zakonske norme koje su suprotne Ustavu RH; te čl. 82., st. I. i čl. 149. Ustava RH, kojima se postupak izmjene ustava čini složenijim (otežanijim) od postupka donošenja zakona. ${ }^{17}$

14 Formalna (ili strukturna) hijerarhija između dviju normi postoji kada je jednom normom određena proizvodnja druge norme. Vidi Guastini, op. cit. u bilj. 1, str. 220 - 221. Formalna hijerarhija postoji između normi Ustava RH kojima se Hrvatskom saboru dodjeljuje zakonodavna vlast i uređuje način njezina izvršavanja i svih hrvatskih zakonskih normi.

15 Guastini, op. cit. u bilj. 1, str. 219 i $221-223$.

16 Ustavni zakon o Ustavnom sudu Republike Hrvatske, Narodne novine, br. 99/1999, 29/2002, 49/2002.

17 Iznimno, postupci izmjene (običnog i organskog) zakona i Ustava RH jednaki su u slučaju usvajanja navedenih izmjena putem referenduma (čl. 87. Ustava RH). 
Ustav RH moguće je mijenjati samo posebnim ustavnim zakonima, donesenima u postupku koji je složeniji od postupka donošenja (običnih i organskih) zakona. Veća složenost postupka mijenjanja Ustava od postupka donošenja (običnih i organskih) zakona očituje se, primjerice, u sljedećem: pravo da predloži donošenje zakona ima svaki zastupnik u Hrvatskom saboru, dok pravo da predloži mijenjanje Ustava ima najmanje jedna petina zastupnika u Hrvatskom saboru; (obične) zakone Hrvatski sabor donosi većinom glasova ako je na sjednici nazočna većina zastupnika (tzv. obična većina) ili, u slučaju organskih zakona (osim onih kojima se uređuju prava nacionalnih manjina), većinom glasova svih zastupnika (tzv. apsolutna većina), dok ustavni zakon o izmjenama ustava Hrvatski sabor donosi dvotrećinskom većinom glasova svih zastupnika; za razliku od postupka donošenja običnog i organskog zakona, Hrvatski sabor ustavni zakon o izmjenama ustava može donijeti tek nakon što je većinom glasova svih zastupnika odlučio da će pristupiti donošenju ustavnog zakona i utvrdio njegov nacrt.

Preciznije, može se reći da je hrvatski Ustav djelomično krut, a djelomično neizmjenljiv. Prvo, Ustavni sud RH je u svojoj praksi razvio doktrinu o "ustavnom identitetu”, a iz priopćenja i obrazloženja nekih odluka ${ }^{18}$ i prema nekim stavovima hrvatske ustavne doktrine ${ }^{19}$ proizlazi da bi Ustavni sud RH mogao odbiti izmjenu ustavnih odredbi kojima su izražene norme koje čine ustavni identitet pravnog poretka Republike Hrvatske. Shvaćanje Ustavnog suda RH o postojanju hrvatskog ustavnog identiteta, koji uključuje i najviše vrednote ustavnog poretka Republike Hrvatske pobrojane u čl. 3. Ustava RH, upućuje na tumačenje strukturnih ustavnih načela (posebice onih koja proizlaze iz čl. 3. Ustava RH) kao "vrhovnih" ustavnih načela koja su nadređena ostalim ustav-

18 Vidi primjerice USRH, Priopćenje o narodnom ustavotvornom referendumu o definiciji braka, Sus-1/2013 od 14. studenoga 2013., Narodne novine, br. 138/2013, USRH, odluka broj: U-VIIR-1159/2015 od 8. travnja 2015., Narodne novine, br. 43/2015, USRH, odluka broj: U-VIIR-1158/2015 od 21. travnja 2015., Narodne novine, br. 46/2015 i USRH, odluka broj: U-III-4149/2014 od 24. srpnja 2015., Narodne novine, br. 89/2015.

19 Vidi Kostadinov, B., Ustavni identitet, u: Bačić, A. (ur.), Dvadeseta obljetnica Ustava Republike Hrvatske, HAZU, Zagreb, 2011., str. 320 - 322; Smerdel, B., Ustavno uređenje europske Hrvatske, Narodne novine, Zagreb, 2013., str. 78; Gardašević, Đ., Neustavni ustavni amandmani i Ustavni sud Republike Hrvatske, u: Bačić, A. (ur.), Konstitucionalizacija demokratske politike, HAZU, Zagreb, 2014., str. 85 - 110; Horvat Vuković, A., "U ime ustava" - materijalne granice promjene ustava, Zbornik Pravnog fakulteta u Zagrebu, sv. 65, br. 3-4, 2015., str. 488 - 494; Omejec, J., Veliki njemački ustav i nepromjenjiva ustavna načela u praksi Saveznog ustavnog suda, u: Zbornik "Pravo i pravda 2015" Pravnog fakulteta Univerziteta u Beogradu, u pripremi, str. 27 - 32, dostupno na https://independent.academia.edu/JasnaOmejec. 
nim normama. Na temelju takvog tumačenja Ustavni sud RH zapravo stvara vrijednosnu hijerarhiju između ustavnih normi - vrhovnih ustavnih načela i "običnih" ustavnih normi. Preostaje vidjeti hoće li takvu vrijednosnu hijerarhiju u nekoj od svojih budućih odluka Ustavni sud RH pretvoriti i u materijalnu hijerarhiju proglašavajući nevaljanim (neustavnim) zakon o izmjenama Ustava RH ili narodni ustavotvorni referendum koji bi za cilj imao izmijeniti navedena vrhovna načela. Drugo, hrvatski Ustav sadržava normu (formuliranu čl. 142., st. 2. Ustava RH) kojom se zabranjuje pokretanje postupka udruživanja koje bi moglo dovesti do obnavljanja jugoslavenskog državnog zajedništva, a koju neki shvaćaju i kao normu kojom se zabranjuje mijenjanje Ustava RH koje bi dovelo ili moglo dovesti do obnove "jugoslavenskog državnog zajedništva”, to jest bilo kojeg oblika "balkanske državne sveze". ${ }^{20}$

Djelomična neizmjenljivost ustava, osobito ona uspostavljena na temelju doktrine o tzv. neizmjenljivim ustavnim načelima, omogućuje, prema Guastiniju, i izraženije poustavljenje pravnog poretka. ${ }^{21}$

(c) Što se tiče sudskog jamstva ustava, Ustav RH pripada skupini zajamčenih ustava jer u svojim čl. 129. i 131. predviđa (sudski) nadzor ustavnosti zakona koji izvršava Ustavni sud RH. Ustav RH pripada skupini ustava koji predviđaju: 1) poseban organ (Ustavni sud RH) kojemu je dodijeljena vlast nadziranja ustavnosti zakona 2) nakon njihova proglašenja i objave (a posteriori) i 3) koji je ovlašten neustavne zakone poništiti ("ukinuti”, prema terminologiji hrvatskog prava) s općim učincima (erga omnes), u okviru 4) apstraktnog i konkretnog nadzora ustavnosti. Dakle, nadzor ustavnosti zakona u Republici Hrvatskoj je centraliziran, naknadan (a posteriori), apstraktan ili konkretan i proizvodi opće učinke.

U hrvatskom pravnom poretku pitanje ustavnosti zakona može nastati izvan konkretnog pravnog spora (npr. građanskog, kaznenog, upravnog) koji se vodi pred nekim redovnim (ne-ustavnim) sudom te uzgredno (incidentalno), tj. u okviru takvog konkretnog pravnog spora kao prethodno pitanje. Kada pitanje

20 Smerdel, op. cit. u bilj. 19, str. 78; Padjen, I., Vjera u narod bez vlasti i vlasništva (II.): Vlast naroda i bezplast puka, Anali Hrvatskog politološkog društva: časopis za politologiju, sv. 10, br. 1, 2013., str. 201. Za navedeno tumačenje čl. 142., st. 2. Ustava RH, prema kojem je "mogući smisao navedene odredbe spriječiti određeni rezultat, tj. dovođenje Republike Hrvatske u bilo kakav oblik jugoslavenskog državnog zajedništva, a ne spriječiti samo jedno od mogućih sredstava, tj. postupak udruživanja, kojim bi se moglo dovesti do takvog rezultata" vidi Burazin, L.; Krešić, M.; Tucak, I., Priručnik za teoriju prava - praktični dio, 2. izdanje, Naklada Breza, Zagreb, 2020., str. 119 - 121.

21 Vidi Guastini, R., op. cit. u bilj. 1, str. 187 - 188. 
neustavnosti nastane izvan konkretnog pravnog spora, ustavnosudski postupak nadzora ustavnosti može zahtjevom pokrenuti jedna petina zastupnika Hrvatskoga sabora, radno tijelo Hrvatskoga sabora, predsjednik Republike Hrvatske, pučki pravobranitelj ${ }^{22}$ (čl. 35., st. 1., podst. 1. - 3. i 6. UZUSRH-a) i predstavničko tijelo jedinice lokalne ili područne (regionalne) samouprave u Republici Hrvatskoj (čl. 36., st. I. UZUSRH-a)23, a prijedlogom svaka fizička i pravna osoba (čl. 38., st. 1. UZUSRH-a). Ustavni sud može postupak ocjene ustavnosti zakona pokrenuti i na vlastitu inicijativu (čl. 38., st. 2. UZUSRH-a). Kada pitanje neustavnosti zakona nastane u okviru konkretnog pravnog spora, zahtjev za ocjenu ustavnosti zakona Ustavnom sudu može podnijeti (ne-ustavni) sud pred kojim se vodi konkretan spor (čl. 35., st. 1., podst. 5. UZUSRH-a).

Ustavni sud RH ovlašten je ocjenjivati ustavnost zakona koji su proglašeni i objavljeni (ex čl. 129., st. 1., podst. 1. Ustava RH). ${ }^{24}$ Iznimno, Ustavni sud može ocjenjivati ustavnost zakona i nakon što su prestali biti na snazi (čl. 129., st. 1., podst. 3. Ustava RH). Dakle, riječ je o naknadnom (a posteriori) nadzoru ustavnosti zakona. ${ }^{25}$

Nadzor ustavnosti zakona u hrvatskom pravnom poretku je apstraktan u svim onim slučajevima u kojima se on pokreće izvan konkretnog pravnog spora koji se vodi pred nekim od redovnih (ne-ustavnih) sudova jer se pitanje ustavnosti ne postavlja s obzirom na konkretno činjenično stanje u nekom konkretnom predmetu i navodnu konkretnu povredu ustavnih prava određene stranke u sporu. Nadzor ustavnosti hrvatskih zakona konkretan je kada zahtjev za ocjenu ustavnosti postavi neki od redovnih sudova zbog pitanja ustavnosti

22 Pučki pravobranitelj može podnijeti zahtjev za ocjenu ustavnosti zakona kada smatra da je zakonom povrijeđeno neko temeljno ljudsko pravo ili sloboda (ex čl. 35. UZUSRH-a i čl. 93. Ustava RH).

23 Sukladno čl. 36., st. 1. UZUSRH-a predstavničko tijelo jedinice lokalne ili područne (regionalne) samouprave u Republici Hrvatskoj može pokrenuti postupak ocjene ustavnosti zakona ako je riječ o zakonima kojima se uređuje ustrojstvo, djelokrug ili financiranje jedinica lokalne i područne (regionalne) samouprave.

24 Ustavni sud RH je u svojoj odluci (USRH, odluka broj: U-I-5654/2011 od 15. veljače 2012., dostupno na https://sljeme.usud.hr/usud/praksaw.nsf) raspravljao o pitanju je li nadležan za ocjenu ustavnosti zakona koji je objavljen, ali još nije stupio na snagu, te zaključio da njegova nadležnost ocjene ustavnosti postoji već od trenutka objave zakona, a ne tek od trenutka njegova stupanja na snagu. Vidi III. glavu navedene odluke, a osobito točke 7.1. i 7.2.

25 Jedina je iznimka prethodni nadzor ustavnosti zakona čije usvajanje se predlaže u postupku referenduma pokrenutog narodnom (građanskom) inicijativom (čl. 95. UZUSRH-a). 
koje se pojavilo u sporu koji vodi, tj. prilikom primjene ustavno spornog zakona u konkretnom predmetu.

Bez obzira na to je li riječ o apstraktnom ili konkretnom nadzoru ustavnosti zakona, odluke Ustavnog suda kojima se ukida zakon ili pojedina zakonska odredba proizvode učinke prema svima (erga omnes) (ex čl. 55., st. 1. i 2. UZUSRH-a).

\section{ASPEKTI POUSTAVLJENJA HRVATSKOG PRAVNOG PORETKA}

U ovome ćemo poglavlju analizom relevantnih primjera sudske prakse utvrđivati koji su od pet Guastinijevih aspekata poustavljenja prisutni u hrvatskom pravnom poretku. Relevantni primjeri ustavnosudskih odluka koji upućuju na postojanje shvaćanja o obvezujućoj snazi svih vrsta ustavnih normi (potpoglavlje 3.1.), korištenja tehnike nadtumačenja ustava (potpoglavlje 3.2.), prilagođujućeg tumačenja zakona (potpoglavlje 3.4.), ocjenjivanja razložnosti zakona i odvagivanja, rješavanja sukoba nadležnosti i ocjenjivanja ustavnosti referendumskih pitanja (potpoglavlje 3.5.) prikupljeni su pretraživanjem prakse Ustavnog suda RH objavljenje na mrežnim stranicama Ustavnog suda RH (https://sljeme.usud.hr/usud/praksaw.nsf). Relevantni primjeri odluka hrvatskih redovnih (ne-ustavnih) sudova koji upućuju na to da hrvatski redovni sudovi (povremeno) neposredno primjenjuju ustavne norme (potpoglavlje 3.3.) prikupljeni su (uglavnom) ${ }^{26}$ pretraživanjem izbora prakse hrvatskih redovnih sudova objavljenog na mrežnim stranicama Portal sudske prakse (https://sudskapraksa. csp.vsrh.hr/home).

\subsection{Obvezujuća snaga ustava}

Aspekt obvezujuće snage ustavnih normi odnosi se na shvaćanje prema kojemu su sve ustavne norme, bez obzira na to je li riječ o preciznim normama pravilima ili pak manje preciznim normama načelima ili programatskim normama, sposobne proizvoditi pravne učinke, a osobito sposobne učiniti nevaljanim zakone (ili zakonske norme) nespojive s ustavom. ${ }^{27}$

Nesporno je da Ustavni sud RH obvezujućima, i u tom smislu sposobnima proizvoditi pravne učinke, smatra precizne ustavne norme pravila kao što su precizne norme o ustrojstvu državnih organa, norme o nadležnosti, norme o

26 Nekoliko javno nedostupnih odluka koje koristimo u radu pribavili smo u osobnim kontaktima sa sudcima redovnih sudova.

27 Vidi Guastini, op. cit. u bilj. 1, str. 188 - 189. 
postupku (npr. zakonodavnom) i norme kojima se pripisuju ustavna prava i time sadržajno ograničava nadležnost državnih organa (osobito zakonodavca). Usto, dosadašnja je praksa Ustavnog suda RH pokazala da on obvezujućima smatra i norme načela, i norme koje izrijekom označava kao načela i norme o ustavnim pravima kada ih shvaća kao načela, te programatske norme. Štoviše, iz dosadašnje se prakse Ustavnog suda RH može zaključiti da određenu sposobnost djelovanja pridaje čak i preambuli Ustava RH (Izvorišnim osnovama). Obvezujuća snaga navedenih vrsta ustavnih normi najjasnije se očituje u slučajevima $\mathrm{u}$ kojima se one nalaze u velikoj premisi rasuđivanja Ustavnog suda RH čiji je zaključak odluka o ukidanju neustavnog zakona ili pojedine zakonske norme.

Tako je primjerice Ustavni sud RH u cijelom nizu svojih odluka od 1993. godine do danas utvrđivao neustavnost zakonskih normi na temelju normi kojima se dodjeljuju ustavna prava i time ograničava (ili čak određuje) sadržaj budućeg normiranja, npr. normi kojima se dodjeljuje pravo na žalbu, pravo na slobodu savjesti i vjeroispovijesti i slobodno javno očitovanje vjere i drugog uvjerenja, pravo vlasništva, pravo na slobodu kretanja i biranja boravišta, pravo na prigovor savjesti, pravo na štrajk, pravo na slobodu okupljanja, pravo na slobodu mišljenja i izražavanja misli, pravo na pravično suđenje, pravo na slobodu udruživanja, pravo na osobni i obiteljski život, dostojanstvo, ugled i čast, pravo na slobodu poduzetništva, biračko pravo, pravo na zaštitu osobnih podataka, pravo na sudjelovanje u obavljanju javnih poslova i prijam u javnu službu. ${ }^{28}$

28 Vidi npr. USRH, odluka broj: U-I-206/1992 od 8. prosinca 1993. (pravo na žalbu), USRH, odluka broj: U-I-231/1990 od 16. veljače 1994. (pravo na slobodu savjesti i vjeroispovijesti i slobodno javno očitovanje vjere i drugog uvjerenja), USRH, odluka broj: U-I-28/1993 od 17. travnja 1994. (pravo vlasništva), USRH, odluka broj: U-I-1037/1995 od 25. rujna 1997. (pravo na slobodu kretanja i pravo vlasništva), USRH, odluka broj: U-I-20/1992 od 18. veljače 1998. (pravo na prigovor savjesti i pravo na slobodu savjesti i vjeroispovijesti i slobodno javno očitovanje vjere ili drugog uvjerenja), USRH, odluka broj: U-I-920/1995 od 15. srpnja 1998. (pravo na štrajk), USRH, odluka broj: U-I-241/1998 od 31. ožujka 1999. (pravo na slobodu okupljanja), USRH, odluka broj: U-I-131/1998 od 3. veljače 2000. (pravo na slobodu mišljenja i izražavanja misli i pravo na pravično suđenje), USRH, odluka broj: U-I884/1997 od 3. veljače 2000. (pravo na slobodu udruživanja), USRH, odluka broj: U-I-241/2000 od 10. svibnja 2000. (pravo na osobni i obiteljski život, dostojanstvo, ugled i čast i pravo na slobodu mišljenja i izražavanja misli), USRH, odluka broj: U-I-646/1999 od 10. svibnja 2000. (pravo na slobodu poduzetništva), USRH, odluka broj: U-I-2051/2007 od 5. lipnja 2007. (biračko pravo), USRH, odluka broj: U-I1962/2008 od 27. rujna 2016. (pravo na zaštitu osobnih podataka), USRH, odluka broj: U-I-3664/2015 i U-I-1007/2016 od 21. studenoga 2017. (pravo na sudjelovanje u obavljanju javnih poslova i prijam u javnu službu). Sve navedene odluke dostupne na https://sljeme.usud.hr/usud/praksaw.nsf. 
Također, Ustavni sud RH već se od svojih početaka za ocjenu ustavnosti zakona koristio i normama koje je izrijekom označavao normama načelima. Tako je Ustavni sud RH u svojoj praksi niz zakona proglasio neustavnima i uklonio ih iz pravnog poretka zbog njihove nesuglasnosti s, primjerice, načelom zakonitosti upravnih akata, načelom diobe vlasti, načelom demokracije, načelom vladavine prava, načelom jednakosti svih pred zakonom i pred sudovima i drugim državnim i inim tijelima koja imaju javne ovlasti, načelom zabrane diskriminacije, načelom presumpcije nedužnosti, načelom socijalne pravde, načelom ustavnosti i zakonitosti, načelom narodnog suvereniteta, načelom političkog predstavljanja, načelom jednakosti tržišnog položaja poduzetnika, načelom porezne jednakosti i pravednosti te načelom razmjernosti u snošenju javnih troškova. ${ }^{29}$

U praksi Ustavnog suda RH zamjetna je i sve češća upotreba tzv. programatskih normi pri ocjeni ustavnosti zakona. Obvezujuća snaga programatskih normi očituje se u tome što se Ustavni sud koristi odredbama kojima su one

29 Vidi npr. USRH, odluka broj: U-I-206/1992 od 8. prosinca 1993. (načelo zakonitosti upravnih akata), USRH, odluka broj: U-I-348/1993 od 5. listopada 1994. (načelo diobe vlasti), USRH, odluka broj: U-I-46/1994 od 30. studenoga 1994. (načelo vladavine prava), USRH, odluka broj: U-I-892/1994 od 20. studenoga 1996. (načelo vladavine prava, načelo diobe vlasti i načelo jednakosti svih pred zakonom i pred sudovima i drugim državnim i inim tijelima koja imaju javne ovlasti), USRH, odluka broj: U-I-697/1995 od 29. siječnja 1997. (načelo jednakosti, načelo zabrane diskriminacije, načelo vladavine prava, načelo presumpcije nedužnosti), USRH, odluka broj: U-I-283/1997 od 12. svibnja 1998. (načelo jednakosti, načelo socijalne pravde i načelo vladavine prava), USRH, odluka broj: U-I-607/1998 od 20. lipnja 2001. (načelo jednakosti tržišnog položaja poduzetnika), USRH, odluka broj: U-I-2494/2002 od 24. ožujka 2004. (načelo ustavnosti i zakonitosti), USRH, odluka broj: U-I-3824/2003 od 28. travnja 2004. (načelo vladavine prava i načelo jednakosti tržišnog položaja poduzetnika), USRH, odluka broj: U-I-764/2004 i dr. od 21. ožujka 2007. (načelo zabrane diskriminacije i načelo jednakosti), USRH, odluka broj: U-I-2051/2007 od 5. lipnja 2007. (načelo narodnog suvereniteta, načelo političkog predstavljanja i načelo jednakosti), USRH, odluka broj: U-IP-3820/2009 i U-IP-3826/2009 i dr. od 17. studenoga 2009. (načelo porezne jednakosti i pravednosti i načelo razmjernosti u snošenju javnih troškova), USRH, odluka broj: U-I-3597/2010 i dr. od 29. srpnja 2011. (načelo demokracije, načelo narodnog suvereniteta, načelo političkog predstavništva), USRH, odluka broj: U-I-4039/2009 i dr. od 18. srpnja 2014. (načelo diobe vlasti), USRH, odluka broj: U-I-2036/2012 od 21. prosinca 2015. (načelo jednakosti), USRH, odluka broj: U-I-3676/2015 i dr. od 9. veljače 2016. (načelo presumpcije nedužnosti), USRH, odluka broj: U-II-6111/2013 od 10. listopada 2017. (načelo demokracije), USRH, odluka broj: U-I-1574/2016 i U-I-1244/2017 od 30. siječnja 2018. (načelo vladavine prava), USRH, odluka broj: U-I-4220/2020 od 20. listopada 2020. (načelo vladavine prava). Sve navedene odluke dostupne na https://sljeme.usud.hr/usud/praksaw.nsf. 
izražene, redovito u spoju s drugim ustavnim odredbama, pri utvrđivanju norme na temelju koje ocjenjuje ustavnost zakona. Ustavni sud RH je, u već prilično dugo razvijanoj praksi, niz zakonskih normi ocijenio neustavnima na temelju, među ostalim, programatskih normi o dužnosti državnih organa da pružaju osobitu zaštitu obitelji, da štite materinstvo, djecu i mladež te stvaraju socijalne, kulturne, odgojne, materijalne i druge uvjete kojima se promiče ostvarivanje prava na dostojan život, da osobitu skrb posvećuju maloljetnicima za koje se roditelji ne brinu, da osobitu skrb posvećuju zaštiti zdravlja ljudi, da potiču i pomažu razvitak znanosti, kulture i umjetnosti. ${ }^{30}$

Konačno, Ustavni sud RH pridao je u nekoliko slučajeva obvezujuću snagu čak i dijelovima teksta Izvorišnih osnova Ustava RH, tj. ustavne preambule ili proslova, premda je zapravo riječ o nenormativnim dijelovima ustavnog teksta. Tako se, primjerice, u dvama od tih slučajeva Ustavni sud RH koristio nenormativnim tekstom Izvorišnih osnova u spoju s normativnim odredbama Ustava RH radi utvrđivanja norme na temelju koje je utvrđena neustavnost podustavne norme. ${ }^{31}$ Pri tome je u jednom od tih slučajeva dio teksta Izvorišnih osnova protumačio kao dio ustavnog identiteta hrvatskog pravnog poretka, tj. odgovarajućih normi načela (tzv. strukturnih ustavnih načela) koje su sastav-

30 Vidi npr. USRH, odluka broj: U-I-697/1995 od 29. siječnja 1997. (pružanje osobite zaštite obitelji), USRH, odluka broj: U-I-902/1999 od 26. siječnja 2000. (poticanje i pomaganje razvitka znanosti, kulture i umjetnosti), USRH, odluka broj: U-I-4892/2004 od 12. ožujka 2008. (osobita skrb posvećena zaštiti zdravlja ljudi), USRH, odluka broj: U-I-3851/2004 od 12. ožujka 2008. (zaštita djece, stvaranje socijalnih, odgojnih, materijalnih i drugih uvjeta kojima se promiče ostvarivanje prava na dostojan život i osobita skrb posvećena maloljetnicima za koje se roditelji ne brinu), USRH, odluka broj: U-I-5578/2013 i U-I-3633/2014 od 18. srpnja 2014. (poticanje i pomaganje razvitka znanosti, kulture i umjetnosti) i USRH, odluka broj: U-I-65181-2009 od 13. lipnja 2017. (zaštita materinstva, djece i mladeži i stvaranje socijalnih, kulturnih, odgojnih, materijalnih i drugih uvjeta kojima se promiče ostvarivanje prava na dostojan život). Sve navedene odluke dostupne na https:// sljeme.usud.hr/usud/praksaw.nsf.

31 Vidi USRH, odluka broj: U-II-433/1994 i dr. od 2. veljače 1995. i USRH, odluka broj: U-I-3597/2010 i dr. od 29. srpnja 2011. Osim u ovim dvama slučajevima, Ustavni sud RH koristio se tekstom Izvorišnih osnova i u USRH, odluka broj: U-II6111/2013 od 10. listopada 2017., radi opravdanja podvodećeg (supsumirajućeg) iskaza u rasuđivanju čiji je zaključak bio poništenje odluke organa lokalne uprave, te u USRH, odluka broj: U-III-3491/2006 i dr. od 7. srpnja 2010., u spoju s normativnim ustavnim odredbama, radi prilagođujućeg tumačenja zakonske odredbe i izvođenja norme u pogledu koje je utvrdio da je redovni sudovi nisu primijenili te da su time povrijedili ustavno pravo vlasništva podnositelja ustavne tužbe, zbog čega je naložio Vladi Republike Hrvatske da podnositeljici isplati primjerenu naknadu. Sve navedene odluke dostupne na https://sljeme.usud.hr/usud/praksaw.nsf. 
ni dio hrvatskog ustavnog identiteta, a kojima se Ustavni sud RH koristi pri nadzoru ustavnosti. ${ }^{32}$

\subsection{Nadtumačenje ustava}

Nadtumačenje ustava je praksa ustavnih sudova da, u slučajevima kada doslovno tumačenje ustavnih odredbi (u spoju s argumentom a contrario) rezultira ustavnopravno "praznim" prostorom u kojem zakonodavac može bez nadzora uređivati određene društvene odnose, proširenim tumačenjem, u spoju s argumentom a simili, iz ustavnog teksta izvedu prešutne, neizražene norme koje im omogućuju nadzor nad svakim (ili gotovo svakim) zakonodavnim aktom. ${ }^{33}$ Pri tome se, kao jedno od učinkovitijih sredstava nadtumačenja, pokazuje shvaćanje ustavnih odredbi kao odredbi kojima se izražavaju (ne precizna pravila, nego) vrlo neodređena načela, što onda omogućuje da se iz njih, odgovarajućim argumentima, izvedu mnogobrojna dodatna preciznija neizražena (implicitna) pravila kojima se ta načela konkretizira i na taj način zapravo dolazi do novih ustavnih normi, koje pak omogućuju širenje ustavnosudskog nadzora nad ustavnošću zakona. ${ }^{34}$

Analiza odluka Ustavnog suda RH pokazuje da se Ustavni sud RH u svojoj praksi koristi tehnikom nadtumačenja ustava, pravnokonstruktivnim argumentima iz postojećih ustavnih normi izvodeći neizražene norme koje zatim upotrebljava kao dio velike premise rasuđivanja o ustavnosti zakona ili pojedine zakonske norme. Evo nekoliko primjera.

Čl. 3. Ustava RH vladavina prava uvrštena je među "najviše [...] vrednote ustavnog poretka Republike Hrvatske i temelj za tumačenje Ustava”. Navedeni dio odredbe Ustavni sud RH tumači kao izraz načela vladavine prava iz kojega je, u svojoj već bogatoj praksi, izveo čitav niz dodatnih, neizraženih načela, poput načela općosti zakona, načela dostupnosti norme, načela pravne sigurnosti (izvjesnosti), načela legitimnih očekivanja, načela jasnoće i određenosti zakonskih odredaba, iz kojih za zakonodavca proizlaze sasvim određena ograničenja u pogledu "pravne kvalitete" koju bi zakoni morali imati kako bi bili u skladu s načelom vladavine prava. ${ }^{35}$

32 USRH, odluka broj: U-I-3597/2010 i dr. od 29. srpnja 2011., dostupno na https:// sljeme.usud.hr/usud/praksaw.nsf.

33 Guastini, op. cit. u bilj. 8, str. 189.

34 Guastini, op. cit. u bilj. 1, str. 194.

35 Vidi npr. USRH, odluka broj: U-I-46/1994 od 30. studenoga 1994., USRH, odluke i rješenja broj: U-I-659/1994 i dr. od 15. ožujka 2000., USRH, odluka broj: U-I- 
Iz čl. 4. Ustava RH, kojim je izraženo načelo diobe vlasti, Ustavni sud RH izveo je neizraženu normu prema kojoj zakonodavac ne može zakonom ni proširivati ni ograničavati ovlasti i dužnosti ustavom pripisane najvišim ustavnim organima unutar svake od triju državnih vlasti. ${ }^{36}$

Iz čl. 129., st. 1., podst. 1. i 2. proizlazi da je Ustavni sud RH nadležan ocjenjivati suglasnost zakona s Ustavom i suglasnost podzakonskih propisa s Ustavom i zakonom. Ustavni sud je iz navedene odredbe, u spoju s odredbom kojom je izraženo načelo ustavnosti i zakonitosti (čl. 5., st. 1. Ustava RH) i odredbom kojom je izražena norma o nadzakonskoj pravnoj snazi preuzetih međunarodnih ugovora (čl. 14l. Ustava RH), izveo dodatnu, neizraženu normu prema kojoj je on nadležan ocjenjivati i suglasnost zakona s međunarodnim ugovorima koji čine dio domaćeg pravnog poretka. ${ }^{37}$

Ustav RH do svojih izmjena iz studenoga 2000. godine (Narodne novine, br. 113/2000) nije izrijekom uređivao načelo razmjernosti. Ipak, Ustavni sud RH izveo je u svojoj praksi prije navedenih izmjena Ustava RH iz spoja više odredbi Ustava RH neizraženo, implicitno načelo razmjernosti kao “opće ustavno

3824/2003 od 28. travnja 2004., USRH, odluka broj: U-I-2510/2001 od 6. prosinca 2006., USRH, odluka i rješenje broj: U-I-722/2009 od 6. travnja 2011., USRH, rješenje broj: U-I-7883/2014 i dr. od 11. srpnja 2017. Sve navedene odluke dostupne na https://sljeme.usud.hr/usud/praksaw.nsf.

36 Vidi USRH, odluke i rješenja broj: U-I-659/1994 i dr. od 15. ožujka 2000., dostupno na https://sljeme.usud.hr/usud/praksaw.nsf.

37 Vidi USRH, odluka broj: U-I-745/1999 od 8. studenoga 2000., dostupno na https:// sljeme.usud.hr/usud/praksaw.nsf. Međutim, u sličnom je slučaju, kada je trebao odlučiti je li nadležan ocjenjivati suglasnost međunarodnog ugovora s Ustavom RH, doslovnim tumačenjem odredbe čl. 129. Ustava RH i u spoju s argumentom a contrario zaključio da u tom slučaju njegova nadležnost ne postoji. Vidi USRH, rješenje broj: U-I-825/2001 od 14. siječnja 2004., dostupno na https://sljeme.usud.hr/usud/ praksaw.nsf. O potonjem shvaćanju Ustavnog suda RH kao primjeru samoograničavanja Ustavnog suda (nasuprot njegovu aktivizmu u nekim drugim slučajevima) vidi Gardašević, op. cit. u bilj. 19, str. 99 - 100. U kasnijim je rješidbama Ustavni sud RH zadržao ovo tumačenje, dopunivši ga pozivanjem na odredbu čl. 141. Ustava $\mathrm{RH}$, prema kojoj se preuzeti "međunarodni ugovori mogu mijenjati ili ukidati samo uz uvjete i na način koji su u njima utvrđeni, ili suglasno općim pravilima međunarodnog prava”. Vidi npr. USRH, rješenja broj: U-I-1583/2000 i U-I-559/2001 od 24. ožujka 2010., Narodne novine, br. 46/2010, i USRH, rješenje broj: U-I-6738/2010 od 11. lipnja 2013., dostupno na https://sljeme.usud.hr/usud/praksaw.nsf. Doduše, Ustavni sud RH mogao je izraz "ukidanje” iz čl. 141. protumačiti i tako da se odnosi na politički akt ukidanja od strane zakonodavnog tijela, a ne na ustavnosudski akt ukidanja koji je po svojoj naravi ustvari akt poništenja, pa bi na taj način otklonio navodnu prepreku ocjeni suglasnosti međunarodnog ugovora s Ustavom iz čl. 141. Ustava RH. 
načelo, koje je imanentno svim Ustavnim odredbama o slobodama i pravima čovjeka i građanina". 38

Iako iz čl. 95., st. 1. UZUSRH-a, koji ima pravnu snagu Ustava, proizlazi da Ustavni sud RH može ocjenjivati ustavnost referendumskog pitanja isključivo na zahtjev Hrvatskog sabora, Ustavni sud RH izveo je iz svoje opće ustavne zadaće jamčenja poštovanja Ustava RH i nadziranja ustavnosti državnog referenduma neizraženu normu prema kojoj je, iznimno, kada utvrdi takvu formalnu i/ili materijalnu protuustavnost referendumskog pitanja ili tako tešku proceduralnu pogrešku koja prijeti narušavanjem ustavnog identiteta Republike Hrvatske, nadležan ocijeniti ustavnost referendumskog pitanja i bez prethodnog zahtjeva Hrvatskog sabora. ${ }^{39}$

Ustavna norma o raspisivanju referenduma na temelju građanske inicijative (koja proizlazi iz čl. 87., st. 3. Ustava $\mathrm{RH}$ ) ne određuje ništa u pogledu obrazlaganja zahtjeva za raspisivanje referenduma. Međutim, Ustavni sud RH, na temelju ocjene o relevantnosti obrazloženja za odlučivanje Hrvatskog sabora i Ustavnog suda RH u pogledu zahtjeva za raspisivanje referenduma i doktrinarne teze o važnosti otvorene rasprave u demokratskom društvu, izvodi neizraženu normu prema kojoj svaki takav zahtjev "mora sadržavati detaljan prikaz činjenica i okolnosti koje su bile povod za referendumsko pitanje u predloženom sadržaju te dostatno i relevantno obrazloženje razloga zbog kojih se traži raspisivanje referenduma". 40

Čl. 87., st. 1. - 3. Ustava RH određuju da se referendum može raspisati o prijedlogu za promjenu Ustava RH, o prijedlogu zakona ili o drugom pitanju iz djelokruga Hrvatskog sabora ili o pitanju koje je važno za neovisnost, jedinstvenost i opstojnost Republike Hrvatske. Iako Ustav RH ne sadržava norme kojima se zabranjuje raspisivanje referenduma o određenim pitanjima, Ustavni sud RH izveo je neizraženu normu prema kojoj su zabranjena referendumska pitanja o prijedlozima zakona koja nisu u skladu s pravnim sustavom kao cjelinom, kao

38 Vidi USRH, odluka i rješenje broj: U-I-673/1996 i dr. od 21. travnja 1999. i USRH, odluka broj: U-I-1156/1999, 26. siječnja 2000. Obje odluke dostupne na https:// sljeme.usud.hr/usud/praksaw.nsf.

39 USRH, Priopćenje o narodnom ustavotvornom referendumu o definiciji braka, SuS-1/2013 od 14. studenoga 2013., Narodne novine, br. 138/2013. Međutim, čini se da je Ustavni sud u kasnijoj odluci ograničio doseg navedene neizražene norme kada je riječ o teškim proceduralnim pogreškama. Vidi USRH, rješenje broj: U-VIIR-3260/2018 od 18. prosinca 2018, t. 10.2., dostupno na https://sljeme.usud. hr/usud/praksaw.nsf.

40 USRH, odluka broj: U-VIIR-4640/2014 od 12. kolovoza 2014., dostupno na https:// sljeme.usud.hr/usud/praksaw.nsf. 
ni ona za koja izrijekom ili iz cjeline Ustava RH proizlazi da su stvar isključive nadležnosti tijela predstavničke demokracije (primjerice, donošenje državnog proračuna i njegova održivost) te ona koja bi prijetila narušavanjem strukturnih obilježja hrvatske ustavne države, to jest njezina ustavnog identiteta, uključujući najviše vrednote ustavnog poretka Republike Hrvatske. ${ }^{41}$

Iz čl. 35. Ustava RH, kojim se svakome jamči štovanje i pravna zaštita osobnog i obiteljskog života i dostojanstva, Ustavni sud RH izveo je neizraženu normu prema kojoj svatko ima pravo na odlučivanje i samoodređenje. Iz norme o pravu svakoga na odlučivanje i samoodređenje Ustavni sud RH izveo je neizraženu normu o pravu svakoga na vlastiti duhovni i tjelesni integritet, a iz ove je norme izveo neizraženu normu prema kojoj žena ima pravo odlučiti o prekidu trudnoće. ${ }^{42}$

\subsection{Neposredna primjena ustavnih normi}

Aspekt neposredne primjene ustavnih normi odnosi se ponajprije na neposrednu primjenu ustavnih normi od strane redovnih sudova, a osobito na one situacije u kojima redovni sudovi ustavne norme upotrebljavaju kao dio velike premise svojega rasuđivanja zbog toga što im se zakon koji bi prima facie trebalo primijeniti na konkretan slučaj čini nepotpunim ili nepravednim. ${ }^{43}$ Hrvatski redovni (tj. ne-ustavni) sudovi neposredno primjenjuju ustavne norme $\mathrm{u}$, primjerice, sljedećim situacijama.

(a) Redovni sudovi na neki način neposredno primjenjuju ustavne norme kada temeljem čl. 37. UZUSRH-a u konkretnom sporu ocijene da zakonska ili podzakonska norma koju bi trebali primijeniti nije u skladu s Ustavom RH i na vlastitu inicijativu pred Ustavnim sudom RH pokrenu pitanje ustavnosti zakona ili drugog propisa. Tako su, primjerice, redovni sudovi od Ustavnog suda zahtijevali ocjenu ustavnosti čl. 13., st. 2. Zakona o izmjenama i dopunama Zakona o potrošačkom kreditiranju (Narodne novine, br. 143/2013 i 147/2013) ${ }^{44}$, čl. 434.

${ }^{41}$ Vidi USRH, odluka broj: U-VIIR-1159/2015 od 8. travnja 2015., Narodne novine, br. $43 / 2015$.

42 Vidi USRH, rješenje broj: U-I-60/1991 i dr. od 21. veljače 2017., Narodne novine, br. 25/2017.

43 Guastini, op. cit. u bilj. 1, str. 195.

44 Vidi USRH, odluka broj: U-I-3541/2015 od 4. svibnja 2016., dostupno na https:// sljeme.usud.hr/usud/praksaw.nsf. 
i 435. Zakona o javnoj nabavi (Narodne novine, br. 120/2016) ${ }^{45}$, čl. 5., st. 2. Zakona o strancima (Narodne novine, br. 130/2011, 74/2013, 69/2017, 46/2018, 66/2019 i 53/2020) i čl. 4l. Zakona o sigurnosnim provjerama (Narodne novine, br. 85/2008 i 86/2012) ${ }^{46}$, dijela čl. 64., čl. 66., st. l. i čl. 70., st. 2. Zakona o porezu na dohodak (Narodne novine, br. 115/2016, 106/2018, 121/2019 i 32/2020). ${ }^{47}$

(b) Nadalje, redovni sudovi primjenjuju ustavne norme i kada odbiju prijedlog stranke da Ustavnom sudu RH upute zahtjev za ocjenu ustavnosti zakonske norme primjenjive u konkretnom slučaju jer odluka o tome da ne upute zahtjev podrazumijeva tumačenje ustavnih odredbi i zaključak da primjenjiva zakonska norma nije nespojiva s Ustavom RH. Tako je, primjerice, redovni sud odbio prijedlog stranke da Ustavnom sudu RH podnese zahtjev za ocjenu ustavnosti pravne norme koja proizlazi iz čl. 91.a Zakona o parničnom postupku (Narodne novine, br. 53/1991, 91/1992, 112/1999, 88/2001, 117/2003, 2/2007 i 84/2008), ocijenivši da ona ne proturječi ustavnom pravu na pristup sudu. ${ }^{48}$

(c) Redovni sudovi u određenom smislu primjenjuju ustavne norme i kada se u konkretnom sporu posluže prilagođujućim tumačenjem primjenjive zakonske odredbe, tj. pripisivanjem zakonskoj odredbi onoga od mogućih značenja koje je spojivo s vrijedećim ustavnim normama, pri tome odbacujući ono ili ona značenja koja s njima nisu spojiva. Upotrebu prilagođujućeg tumačenja od redovnih sudova zahtijeva i Ustavni sud RH:

“[u]stavne vrednote, načela i jamstva ostvaruju puni smisao i potvrdu općim ili pojedinačnim pravnim aktima koji čine pravni poredak Republike Hrvatske. Slijedom izravnog vertikalnog djelovanja odredaba Ustava, sudska, upravna i druga tijela koja obnašaju javne ovlasti, imaju obvezu tumačiti i primjenjivati pravne propise na način koji je sukladan zahtjevima koji proizlaze iz Ustava kao temeljnog odnosno najvišeg pravnog propisa unutar pravnog poretka Republike Hrvatske". ${ }^{4}$

45 Vidi USRH, odluka broj: U-I-2911/2017 od 5. veljače 2019., dostupno na https:// sljeme.usud.hr/usud/praksaw.nsf.

46 Vidi USRH, odluka broj: U-I-2591/2019 od 24. lipnja 2020., dostupno na https:// sljeme.usud.hr/usud/praksaw.nsf.

47 Vidi USRH, odluka broj: U-I-1072/2019 od 7. srpnja 2020., dostupno na https:// sljeme.usud.hr/usud/praksaw.nsf.

48 Vidi Vrhovni sud RH, presuda broj: Revr 1483/11-3 od 25. rujna 2012., dostupno na https://sudskapraksa.csp.vsrh.hr/home.

49 USRH, odluka broj: U-I-144/2019 i dr. od 29. siječnja 2020., t. 20.1., dostupno na https://sljeme.usud.hr/usud/praksaw.nsf. 
Primjerice, suočen s dvjema mogućnostima tumačenja odredbe Zakona o nabavi i posjedovanju oružja građana (Narodne novine, br. 94/2018 i 42/2020), doslovnim (gramatičkim) tumačenjem, koje je, prema ocjeni nadležnog sudca, nespojivo s Ustavom RH jer nerazmjerno zadire u ustavno pravo vlasništva, i ciljnim tumačenjem, koje ne proturječi Ustavu RH, sudac je izabrao potonje tumačenje, tj. normu kojom se izbjegava proturječje s Ustavom RH. ${ }^{50}$

(d) U užem smislu redovni sudovi neposredno primjenjuju ustavne norme kada u podastrtom im sporu odluku donose neposredno na temelju ustavne norme, tj. kada ustavna norma (sama ili u spoju s drugim, podustavnim normama) čini veliku premisu sudačkog rasuđivanja čiji je rezultat pojedinačan i konkretan propis (sudska odluka). Primjerice, redovni sudovi su na taj način neposredno primijenili ustavnu normu kada su, primjenom ustavne norme o pravu vlasništva (čl. 48., st. 1. Ustava RH), nadležnom upravnom organu naložili vraćanje oduzetog oružja tužitelju ${ }^{51}$; kada su, primjenom ustavne norme o pravu na poštovanje privatnog života (čl. 35. Ustava RH), tužitelju odobrili stalni boravak u Republici Hrvatskoj ${ }^{52}$; kada su, primjenom ustavnog načela o socijalnoj državi (čl. 3. Ustava RH), ustavne norme prema kojoj država slabim, nemoćnima i drugim, zbog nezaposlenosti ili nesposobnosti za rad, nezbrinutim osobama treba osiguravati pravo na pomoć za podmirenje osnovnih životnih potreba (čl. 58., st. l. Ustava RH) i programatske ustavne norme prema kojoj država posebnu skrb treba posvećivati zaštiti osoba s invaliditetom i njihovu

50 "Gramatičko tumačenje odredbe članka 11. stavka 2. točke 4. Zakona o nabavi i posjedovanju oružja građana upućuje na to da zapreku za izdavanje/produženje oružnog lista čini bilo koji prekršaj u području lovstva. Međutim, sagledavajući cjelinu ove odredbe, fokusirane primarno na djela koja upućuju na ozbiljan rizik od zlouporabe oružja (nasilje, zlouporaba droga, oružja ili eksplozivnih tvari), Sud je suglasan s argumentacijom tužitelja da ciljno tumačenje spomenute odredbe (uključujući prilagođavajuće tumačenje zakonske norme u skladu s ustavnom i konvencijskom normom) ne upućuje na zaključak da ta odredba obuhvaća i prekršaje u području lovstva koji ni na koji način ne upućuju na rizik zlouporabe oružja, u koje okvire nedvojbeno ulazi i djelo za koje je tužitelj proglašen krivim (uz oslobođenje od kazne)." Naime, prema doslovnom tumačenju navedene zakonske odredbe, oružje bi se oduzimalo i u slučajevima počinjenja nekog od prekršaja u području lovstva koji ni na koji način ne upućuje na rizik zlouporabe oružja, a to bi, prema shvaćanju nadležnog sudca, predstavljalo nerazmjerno zadiranje u ustavno pravo vlasništva. Vidi Upravni sud u Rijeci, presuda broj: 2 UsI-100/2021-5 od 16. veljače 2021. Presuda je u posjedu autorâ, ali nije javno dostupna.

51 Vidi Upravni sud u Rijeci, presuda broj: 2 UsI-1293/2018-42 od 8. travnja 2020. Presuda je u posjedu autorâ, ali nije javno dostupna.

52 Vidi Upravni sud u Rijeci, presuda broj: 2 UsI-1298/2019-15 od 29. siječnja 2020. Presuda je u posjedu autorâ, ali nije javno dostupna. 
uključivanju u društveni život (čl. 58., st. 2. Ustava RH), tužitelju odobrili status njegovatelja bračnog druga ${ }^{53}$; kada su, primjenom ustavne norme o pravu na zdrav život (čl. 70., st. l. Ustava RH), programatske ustavne norme prema kojoj država osigurava uvjete za zdrav okoliš (čl. 70., st. 2. Ustava RH) i programatske ustavne norme prema kojoj država osobitu skrb treba posvećivati zaštiti zdravlja ljudi, prirode i ljudskog okoliša (čl. 70., st. 3. Ustava RH), utvrdili obvezu Republike Hrvatske da tužitelju nadoknadi štetu nastalu zbog propusta države da obilježi minirana područja ${ }^{54}$; kada su, primjenom ustavne norme o pravu na dom (čl. 34. Ustava RH), odbili tužbeni zahtjev za iseljenje tuženika. ${ }^{55}$

\subsection{Prilagođujuće tumačenje zakona}

Tehnika prilagođujućeg tumačenja zakona je tehnika koju ustavni sudovi koriste kada su suočeni sa zahtjevom za ocjenu ustavnosti neke zakonske odredbe koju je moguće protumačiti na barem dva načina, od kojih je jedan nespojiv, a drugi spojiv s ustavom. U tom slučaju, kako ne bi izbacivali iz poretka spornu odredbu i tako stvorili pravnu prazninu, ustavni sudovi odabiru ono tumačenje zakonske odredbe koje je spojivo s ustavom, proglašavajući neustavnim s ustavom nespojivo tumačenje. Prilagođujuće tumačenje je tumačenje "kojim se zakon prilagođuje, usklađuje s (naravno, prethodno protumačenim) ustavom, izborom - u slučaju suočavanja s dvostrukom tumačenjskom mogućnosti - značenja (tj. norme) kojim se izbjegava svako proturječje između zakona i ustava". ${ }^{56}$

53 Vidi Upravni sud u Rijeci, presuda broj: 2 UsI-1594/15-15 od 29. lipnja 2016., dostupno na https://sudskapraksa.csp.vsrh.hr/home.

54 Vidi Županijski sud u Zadru, presuda broj: 19 Gž-2452/14-2 od 19. travnja 2016. (po žalbama tužitelja i tuženice izjavljenima protiv presude Općinskog suda u Zadru broj P-1309/13 od 7. srpnja 2014. godine), dostupno na https://sudskapraksa. csp.vsrh.hr/home. U konačnici je tužbeni zahtjev ipak odbijen zbog nastupa zastare zahtjeva za naknadu štete.

55 Vidi Županijski sud u Rijeci, presuda broj: Gž-2289/2017-2 od 13. ožujka 2019. (po žalbi tužitelja podnesenoj protiv presude Općinskog suda u Splitu br. Pst-884/14 od 1. rujna 2017.), dostupno na https://sudskapraksa.csp.vsrh.hr/home. Drugostupanjski sud preinačio je presudu prvostupanjskog suda jer je utvrdio da njome nije pravilno odvagnuto pravo na dom i pravo vlasništva te je prevagu dao pravu vlasništva. Dakle, ustavna norma o pravu na dom dio je velike premise rasuđivanja prvostupanjskog suda. Veliku premisu rasuđivanja drugostupanjskog suda čini zakonska norma o pravu na iseljenje zaštićenog najmoprimca (kao zakonodavna konkretizacija ustavnog prava vlasništva).

56 Guastini, op. cit. u bilj. 1, str. 198. 
Ustavni sud RH koristi se tehnikom prilagođujućeg tumačenja zakona, čini se, barem od 2015. godine. Evo nekoliko primjera.

(1) Odredba ustavnog amandmana (čl. 31., st. 4. Ustava RH) propisuje da ne zastarijevaju kaznena djela ratnog profiterstva i kaznena djela iz procesa pretvorbe i privatizacije, a zakonska odredba (čl. 1. Zakona o nezastarijevanju kaznenih dijela ratnog profiterstva i kaznenih dijela iz procesa pretvorbe i privatizacije; dalje u tekstu: ZoNKD-RPiPP), razrađujući navedeni ustavni amandman, da se za kaznena djela ratnog profiterstva i kaznena djela iz procesa pretvorbe i privatizacije kazneni progon može poduzeti i nakon isteka rokova za zastaru kaznenog progona propisanih zakonom. Odlučujući o ustavnosti navedenih odredbi, Ustavni sud RH ustvrdio je: "te se dispozicije (i ustavna i zakonska) moraju tumačiti i primjenjivati tako da u cijelosti budu usklađene s temeljnim vrijednostima na kojima počiva nacionalni Ustav, tako da njihov krajnji ishod ne dovede do neustavnih posljedica" ${ }^{57}$ Prema prilagođujućem (usklađujućem) tumačenju Ustavnog suda RH, ove odredbe znače da je zastara zabranjena odnosno da postoji mogućnost progona i nakon isteka rokova za zastaru progona samo za ona kaznena djela ratnog profiterstva i kaznena djela iz procesa pretvorbe i privatizacije za koja već nije nastupila zastara progona prije donošenja ustavnog amandmana (16. lipnja 2010). Ovakvim tumačenjem Ustavni sud RH nastoji značenje zakonske odredbe i značenje odredbe ustavnog amandmana prilagoditi ustavnim načelima koja su "ugrađena u same temelje hrvatskog ustavnog poretka". ${ }^{58}$ Prema Ustavnom sudu RH načelo vladavine prava "zahtijeva od države da se ne miješa retroaktivno u slučajeve u kojima je već prije nastupila zastara kaznenog progona"59, odnosno u demokratskoj državi utemeljenoj na vladavini prava "nije dopušteno retroaktivno propisivati mogućnost kaznenog progona za kaznena djela [...] za koja je već nastupila zastara tog progona”. ${ }^{60}$ Prema tome, zakonska odredba ZoNKD-RPiPP-a i odredba ustavnog amandmana ostaju na snazi, ali u značenju koje im je pripisao Ustavni sud RH.

(2) Čl. 434., st. 4. Zakona o javnoj nabavi (Narodne novine, br. 120/2016) određeno je: "Ako Visoki upravni sud Republike Hrvatske poništi odluku Državne komisije, svojom će presudom odlučiti i o žalbi u postupku javne nabave." Odbijajući zahtjev za ocjenu ustavnosti navedene odredbe, Ustavni sud RH utvrdio je da bi odredbu trebalo tumačiti na način da Visoki upravni sud treba

57 USRH, odluka broj: U-III-4149/2014 od 24. srpnja 2015., t. 117., Narodne novine, br. $89 / 2015$.

58 Ibid.

59 Ibid.

60 Ibid., t. 123. 
donijeti odluku o ekonomskoj svrsishodnosti odluke naručitelja javne nabave kada god je to moguće, no da bi, iznimno, Visoki upravni sud donošenje te odluke mogao naložiti Državnoj komisiji "ako postoje uvjerljivi razlozi zbog kojih bi donošenje takve odluke u postupku upravnog spora dovelo do ugroze pojedinačnog interesa stranaka u postupku odnosno općeg interesa zaštite svrhovitosti javne nabave u mjeri koja bi po svom karakteru ili učincima predstavljala povredu [...] jamstva pravičnog suđenja" ${ }^{61}$ Tumačenje navedene odredbe prema kojem bi Visoki upravni sud uvijek sam morao donijeti takvu odluku, "iako to ne bi bilo objektivno moguće u konkretnom predmetu", a "čime bi bio ugrožen interes stranaka da se u konačnici o njihovom sporu odluči na temelju svih relevantnih okolnosti specifičnih za konkretan postupak, odnosno opći interes svrhovitosti javne nabave" bilo bi nespojivo s Ustavom RH jer bi, prema stajalištu Ustavnog suda RH, predstavljalo "nerazmjerno ograničenje ustavnog jamstva pravičnosti”. ${ }^{62}$

(3) Čl. 13., st. 2. Zakona o udomiteljstvu (ZoU) (Narodne novine, br. 115/2018) određeno je: "Udomiteljstvo iz stavka 1. ovoga članka mogu obavljati: baka, djed, stric, teta, ujak, braća/polubraća, sestre/polusestre, unuci te njihovi bračni/izvanbračni drugovi." Odlučujući o zahtjevima i prijedlozima za ocjenu ustavnosti navedenih odredbi i njihovo ukidanje, koji su obrazloženi tvrdnjom da se izostavljanjem iz teksta ZoU-a osoba koje žive u životnom i u neformalnom životnom partnerstvu te osobe diskriminiraju po osnovi spolne orijentacije (čl. 14., st. 1. Ustava RH), Ustavni sud RH je utvrdio da "osporene zakonske odredbe, iz kojih je svjesnim odabirom predlagatelja zakona izostavljena određena društvena skupina", protumačene gramatički, "proizvode generalne diskriminatorne učinke prema društvenoj skupini istospolno orijentiranih osoba koje žive u životnim i neformalnim životnim partnerstvima, za što nema ni racionalnog opravdanja ni legitimnog cilja ili je s legitimnim ciljevima ZoU-a, kao cjeline, u značajnom nerazmjeru". ${ }^{3} \mathrm{~S}$ obzirom na to da bi "puko ukidanje osporenih zakonskih odredaba dovelo [...] do praznine u postojećem modelu javne usluge udomljavanja i kao takvo [...] izazvalo štetne posljedice za prava i interese korisnika udomiteljstva", Ustavni sud nije ukinuo sporne odredbe, nego je sudove i druge organe obvezao da ih tumače i primjenjuju "na način koji će svim osobama pod jednakim uvjetima omogućiti sudjelovanje u javnoj usluzi

${ }_{61}$ USRH, odluka broj: U-I-2911/2017 od 5. veljače 2019., t. 16.1., dostupno na https:// sljeme.usud.hr/usud/praksaw.nsf.

62 Ibid., t. 16.2.

63 USRH, odluka broj: U-I-144/2019 i dr. od 29. siječnja 2020., t. 29.1., dostupno na https://sljeme.usud.hr/usud/praksaw.nsf. 
udomljavanja, dakle, neovisno o tome živi li potencijalni udomitelj u životnom ili neformalnom životnom partnerstvu". ${ }^{64}$

\subsection{Utjecaj ustava na političke odnose}

Ovaj se aspekt poustavljenja odnosi na različite načine na koje ustavne norme mogu utjecati na političke odnose. Primjerice, u poredcima u kojima je ustavnom sudu dodijeljena vlast rješavanja sukoba nadležnosti između ustavnih organa, a takvi se sukobi često svode na političke sukobe između tih organa (primjerice, predsjednika republike, parlamenta i vlade), ustavni sudovi imaju prilike razriješiti navedene političke sukobe pravnim putem, na temelju ustavnih normi. ${ }^{65}$ Nadalje, oni primjenom ustavnih normi mogu znatno utjecati na političke odnose i u poredcima u kojima im je dodijeljena vlast nadziranja ustavnosti referendumskih pitanja. Naime, takva se pitanja u konačnici svode na politički sukob "narodne" zakonodavne vlasti i zakonodavne vlasti parlamenta. ${ }^{66}$ Zatim, ustavne norme utječu na političke odnose i $u$ onim poredcima $u$ kojima se ustavni sudovi koriste posebno razvijenim tehnikama za nadziranje "političke diskrecije" zakonodavca, primjerice tehnikom ocjenjivanja razložnosti zakona

64 Ibid., t. 29.2. i 29.3. U sličnoj prijašnjoj situaciji Ustavni sud RH također nije ukinuo zakonske odredbe čiju se ustavnost osporavalo, no nije ih ni prilagođujuće protumačio, nego je o nastaloj neustavnosti odlučio obavijestiti zakonodavca kako bi se ona otklonila u zakonodavnom postupku. "[P]olazeći od članka 61. Ustava koji priznaje dvije zajednice obitelji, a uvažavajući pravnu narav i svrhu obiteljske mirovine u sustavu mirovinskog osiguranja, [...] Ustavni sud utvrđuje da bi ZOMO-om trebale biti uređene i pretpostavke za priznavanje prava na obiteljsku mirovinu ne samo bračnim udovicama, odnosno udovcima, već i izvanbračnim udovicama, odnosno udovcima. Stoga će Ustavni sud [...] izvijestiti Hrvatski sabor o toj uočenoj pojavi neustavnosti, odnosno o potrebi odgovarajuće dopune ZOMO-a, kako bi se zakonom priznalo i pravo izvanbračnih drugova na obiteljsku mirovinu u sustavu mirovinskog osiguranja uređenog ZOMO-om. Ustavni sud se, naime, u ovom slučaju ne može poslužiti ovlašću iz članka 130. stavka 1. Ustava i članka 55. stavka 1. Ustavnog zakona, jer bi ukidanjem članka 21. stavka 1. točke 1. ZOMO-a neosnovano ukinuo pravo na obiteljsku mirovinu i bračnoj udovici/udovcu (iz članka 62. ZOMO-a, naime, razvidno je da se udovicom/udovcem u smislu osporenog članka 21. stavka 1. točke 1. ZOMO-a smatraju samo bračni drugovi), čime se ne bi postigla svrha zbog koje je predlagateljica Ustavnom sudu podnijela prijedlog za ocjenu suglasnosti s Ustavom članka 21. stavka 1. točke 1. ZOMO-a”. USRH, odluka broj: U-I-1152/2000 i dr. od 18. travnja 2007., dostupno na https://sljeme.usud.hr/usud/ praksaw.nsf.

Ibid., str. 203 - 204. 
i tehnikom odvagivanja ustavnih načela. ${ }^{67}$ Korištenjem takvih tehnika ustavni sudovi zalaze u područja koja su se inače smatrala područjima zakonodavne diskrecije, obarajući zakonodavne političke odluke glede sadržaja nekog pravnog uređenja na temelju svojih vrijednosnih ocjena. Konačno, za ustav se može reći da utječe na političke odnose i onda kada ga ustavni organi i važni politički čimbenici upotrebljavaju kako bi opravdali svoje i/ili kritizirali tuđe postupke. ${ }^{68}$

Svi se ovi načini utjecaja ustavnih normi na političke odnose mogu zamijetiti i u hrvatskom pravnom poretku. Ustav RH na političke odnose u Republici Hrvatskoj utječe barem na sljedeće načine.

(a) Čl. 81. i 82. UZUSRH-a Ustavnom sudu RH (uz ostale nadležnosti) dodijeljena je i vlast rješavanja (pozitivnog i negativnog) sukoba nadležnosti ${ }^{69}$ između tijela državne vlasti (zakonodavne, izvršne i sudbene). Od 1993. godine Ustavni sud RH imao je priliku rješavati takve sukobe nadležnosti više puta, a najčešće u slučajevima sukoba između sudbenih i upravno-izvršnih organa. Slučajevi su uključivali brojne sudbene organe (prekršajni, trgovački, općinski i upravni sudovi) i upravno-izvršne organe (uprave Ministarstva financija, Ministarstvo pravosuđa, uredi državne uprave u županijama, uredi županija, upravni odjeli općina). Ipak, Ustavni sud RH još uvijek nije odlučivao o sukobu nadležnosti između vrhovnih ustavnih i političkih organa poput Hrvatskog sabora, Vlade RH i predsjednika Republike, čije bi rješenje predstavljalo značajan utjecaj na političke odnose u Republici Hrvatskoj.

(b) Čl. 95., st. 1. Ustavnog zakona o Ustavnom sudu Republike Hrvatske Ustavnom se sudu dodjeljuje vlast preventivnog nadzora dopuštenosti zahtjeva za održavanje narodnog referenduma. Ustavni sud RH može obavljati takvu vlast na zahtjev Hrvatskog sabora, ali i, iznimno, sukladno neizraženoj normi koju je sam konstruirao, bez prethodnog zahtjeva Hrvatskog sabora. ${ }^{70}$ Ustavni sud RH odlučivao je do kraja 2020. tri puta o sukladnosti referendumskog pitanja s Ustavom RH, i to o pitanjima glede službene uporabe jezika i pisma pripadnika nacionalne manjine (2014. . $^{71}$, obavljanja pratećih i neovisnih djelatnosti u

67 Ibid., str. $204-206$.

68 Ibid., str. 203.

69 Pozitivni sukob nadležnosti uređen je čl. 81., a negativni čl. 82. UZUSRH-a.

70 Vidi gore potpogl. 3.2.

71 Vidi USRH, odluka broj: U-VIIR-4640/2014 od 12. kolovoza 2014., Narodne novine, br. 104/2014, i USRH, rješenje broj: U-VIIR-4640/2014 od 15. listopada 2014. Narodne novine, br. 130/2014. 
javnom sektoru (2015.) ${ }^{72}$ i davanja hrvatskih autocesta u koncesiju (2015.). ${ }^{73} \mathrm{U}$ svim je trima odlukama zabranio raspisivanje referenduma o predloženom referendumskom pitanju ocijenivši referendumsko pitanje neustavnim, na taj način spriječivši ostvarivanje tzv. protuvlasti naroda u odnosu na zakonodavnu vlast.

(c) Čl. 14., st. 2. Ustava RH uređeno je načelo jednakosti svih pred zakonom. Ustavni sud RH navedenim se načelom koristi kao argumentacijskim sredstvom za ocjenu razložnosti (razumnosti, opravdanosti) zakonskih razlikovanja, polazeći od toga da objektivno jednake situacije treba uređivati jednako, a objektivno različite situacije različito. Evo nekoliko primjera.

Ocjenjujući ustavnost čl. 39., st. 3. Ovršnog zakona (Narodne novine, br. 112/2012, 25/2013 i 93/2014), Ustavni sud RH utvrdio je da je navedena odredba neustavna zbog, među ostalim, povrede ustavnog načela jednakosti. ${ }^{74}$ Hrvatski sabor je, naime, samo jednoj podskupini ovrhovoditelja ("ovrhovoditelja-zaposlenika") dodijelio pravo "na poziv na ispravak prijedloga za ovrhu" s ciljem da im povoljnijim postupanjem s nepotpunim prijedlozima za ovrhu olakša ostvarenje prava na rad i vraćanje na rad ili u službu. Međutim, Ustavni sud RH ocijenio je takvo rješenje Hrvatskog sabora kao nerazložno (neracionalno, nerazumno, neopravdano) privilegiranje jedne skupine ovrhovoditelja u odnosu na sve ostale ovrhovoditelje i stoga kao neustavno.

Ustavni sud RH ukinuo je čl. 1. Zakona o izmjeni i dopuni Zakona o plaćama sudaca i drugih pravosudnih dužnosnika (Narodne novine, br. 17/2004), smatrajući da Hrvatski sabor nije imao opravdane razloge za nejednako uređenje prava sudaca i drugih pravosudnih dužnosnika u odnosu na ista prava drugih istovrsnih skupina adresata kojima se plaće isplaćuju iz državnog proračuna. ${ }^{75}$

Ustavni sud RH ukinuo je čl. 20., st. I. Zakona o obrtu (Narodne novine, br. 77/1993, 90/1996, 64/2001, 71/2001 - ispravak, 49/2003 - pročišćeni tekst, 68/2007 i 79/2007 - ispravak), ocijenivši da ne postoji razumno opravdanje za njime uspostavljenu nejednakost u pogledu opsega odgovornosti obrtnika u

2 Vidi USRH, odluka broj: U-VIIR-1159/2015 od 8. travnja 2015., Narodne novine, br. $43 / 2015$.

73 Vidi USRH, odluka broj: U-VIIR-1158/2015 od 21. travnja 2015., Narodne novine, br. $46 / 2015$.

74 Vidi USRH, odluka broj: U-I-2881/2014 i dr. od 1. lipnja 2016., Narodne novine, br. $55 / 2016$.

75 Vidi USRH, odluka broj: U-I-764/2004 i dr. od 21. ožujka 2007., t. 13., Narodne novine, br. 34/2007. 
odnosu na opseg odgovornosti trgovaca pojedinaca (kao apsolutno usporedive skupine), a onda i trgovačkih društava (kao relativno usporedive skupine). ${ }^{76}$

U svim je ovakvim slučajevima Ustavni sud RH svojom vrijednosnom odlukom o razložnosti zakonskog razlikovanja nadvladao "političku" odluku Hrvatskog sabora.

(d) Čl. 16., st. 2. Ustava RH uređeno je načelo razmjernosti ograničenja ustavnih prava i sloboda. Ustavni sud RH koristi se navedenim načelom, putem tehnike odvagivanja, kako bi ocijenio je li zakonodavac nekom zakonskom mjerom, premda je njome konkretizirao neko ustavno pravo ili slobodu, istodobno nerazmjerno ograničio neko drugo ustavno pravo ili slobodu. Riječ je o tehnici koja se sastoji u uspostavljanju tzv. pomične vrijednosne hijerarhije između dvaju ustavnih načela, što znači da "ustavni sud ne odmjerava vrijednost dvaju načela in abstracto i jednom za svagda, nego pak ocjenjuje mogući utjecaj njihove primjene na konkretan slučaj". 77

Prvi primjer. Čl. 8., st. 1. Zakona o ograničavanju uporabe duhanskih proizvoda (Narodne novine, br. 128/1999) zabranjuje se prodaja duhanskih proizvoda iz automatskih naprava. Navedena se zakonska odredba može shvatiti kao povreda poduzetničke i tržišne slobode iz čl. 49. Ustava RH ili konkretizacija prava na zdrav život iz čl. 70., st. I. Ustava RH. Ocjenjujući ustavnost čl. 8., st. 1. Zakona o ograničavanju uporabe duhanskih proizvoda (Narodne novine, br. 128/1999), Ustavni sud RH utvrdio je da je navedena odredba neustavna jer je njome narušena pravična ravnoteža koja mora postojati između zaštite poduzetničkih sloboda (i vlasničkih prava), s jedne strane, i zahtjeva za ostvarenjem javnih interesa radi zaštite zdravlja ljudi, s druge strane. ${ }^{78}$ Dakle, Ustavni sud RH je, odvagivanjem načela slobode poduzetništva (i prava vlasništva) i prava na zdrav život, uspostavio vrijednosnu hijerarhiju između navedenih načela u konkretnom slučaju i time ocjenu Hrvatskog sabora (prema kojoj je pravo na zdrav život nadvladalo slobodu poduzetništva) zamijenio svojim vrijednosnim sudom (prema kojem je sloboda poduzetništva u konkretnom slučaju nadvladala pravo na zdrav život). ${ }^{79}$

76 Vidi USRH, odluka broj: U-I-2771/2008 od 17. ožujka 2010., t. 11.2., dostupno na https://sljeme.usud.hr/usud/praksaw.nsf.

77 Više o tehnici odvagivanja i tzv. pomičnoj vrijednosnoj hijerarhiji vidi u Guastini, op. cit. u bilj. 1, str. $278-280$.

78 Vidi USRH, odluka broj: U-I-1156/1999 od 26. siječnja 2000., Narodne novine, br. $14 / 2000$.

79 Za teorijsku analizu vrste sukoba normi u navedenom primjeru vidi Burazin, L., Conflicts between Fundamental Rights Norms, u: Duarte, D., Sampaio, J. S. (ur.), Proportionality in Law, Springer, Dordrecht, 2018., str. 113 - 114. 
Drugi primjer. Ustavni sud RH ukinuo je, među ostalim, dio čl. 1., st. 3. Zakona o izmjenama i dopunama Zakona o javnom okupljanju (Narodne novine, br. 150/2005) kojim se mirno okupljanje i javni prosvjed zabranjuju najmanje 100 metara od objekta u kojem je smješten predsjednik Republike Hrvatske, smatrajući da Hrvatski sabor tim dijelom zakonske odredbe nije ostvario pravilnu ravnotežu između prava na slobodu javnog okupljanja i suprotstavljenih prava onih koji žive, rade ili obavljaju druge poslove na mjestima na kojima se odvija javno okupljanje. ${ }^{80}$ Prema ocjeni Ustavnog suda RH, štiteći ustavna prava na privatnost, na mirno uživanje vlasništva, na slobodu kretanja, Hrvatski sabor istodobno je nerazmjerno ograničio ustavno pravo na javno okupljanje. Ukidanjem spornog dijela odredbe Ustavni sud RH zamijenio je vrijednosni sud Hrvatskog sabora o odnosu ovih ustavnih prava u konkretnom slučaju (okupljanje najmanje 100 metara od objekta u kojem je trenutačno smješten predsjednik Republike) vlastitim vrijednosnim sudom.

(e) Konačno, utjecaj Ustava RH na političke odnose u Republici Hrvatskoj očituje se i u svim onim situacijama u kojima hrvatski ustavni organi i politički čimbenici (npr. političke stranke) opravdavaju svoje postupke na temelju ustavnih normi ili na temelju njih kritiziraju tuđe postupke. Primjetno je da se u posljednjih desetak godina hrvatski ustavni organi, njihovi članovi, političke stranke i političari sve češće pozivaju na Ustav RH u političkom diskursu, a što je popraćeno i sve zamjetnijim interesom medija za ustavnopravne analize hrvatskih ustavnih stručnjaka.

\section{ZAKLJUČAK}

Cilj ovoga rada bio je opisati u čemu se sastoji trenutačni stadij poustavljenja hrvatskog pravnog poretka. Preciznije, cilj je bio utvrditi koji su elementi poustavljenja zastupljeni u hrvatskom pravnom poretku. Poustavljenost hrvatskog pravnog poretka utvrđivali smo primjenjujući Guastinijev teorijski model poustavljenja pravnog poretka, koji se sastoji od tri nužna uvjeta i pet aspekata poustavljenja pravnih poredaka. Analizom relevantnih izvora prava, osobito Ustava RH i Ustavnog zakona o Ustavnom sudu Republike Hrvatske, utvrdili smo da hrvatski pravni poredak ispunjava sva tri nužna uvjeta poustavljenja hrvatskog pravnog poretka. Ustav RH je dug, krut i sudski zajamčen ustav. Prisutnost pojedinih aspekata poustavljenja pravnog poretka utvrdivali smo na temelju argumentacijske analize relevantnih odluka Ustavnog suda RH i odluka

80 Vidi USRH, odluka broj: U-I-295/2006 i U-I-4516/2007 od 6. srpnja 2011., t. 36. i dalje, dostupno na https://sljeme.usud.hr/usud/praksaw.nsf. 
hrvatskih redovnih (ne-ustavnih) sudova. Analizirana ustavnosudska praksa i praksa redovnih sudova pokazala je da postoje značajne indicije da je u hrvatskom pravnom poretku u nekoj mjeri zastupljeno svih pet aspekata poustavljenja iz Guastinijeva teorijskog modela. Ustavni sud RH smatra da sve ustavne norme imaju obvezujuću snagu (bez obzira na to je li riječ o preciznim ustavnim pravilima ili normama načelima i programatskim normama), u svojoj praksi koristi se tehnikama nadtumačenja ustava i prilagođujućeg tumačenja zakona, a redovni sudovi povremeno neposredno primjenjuju ustavne norme i ustavne norme (na različite načine) utječu na političke odnose u Republici Hrvatskoj.

\section{LITERATURA}

\section{Knjige i članci:}

Atienza, M., Manero, J. R., A Theory of Legal Sentences, Kluwer Academic Publishers, Dordrecht, 1998.

Burazin, L., Conflicts between Fundamental Rights Norms, u: Duarte, D., Sampaio, J. S. (ur.), Proportionality in Law, Springer, Dordrecht, 2018., str. 111 - 117.

Burazin, L.; Krešić, M.; Tucak, I., Priručnik za teoriju prava - praktični dio, 2. izdanje, Naklada Breza, Zagreb, 2020.

Chiassoni, P., Constitutionalism Out of a Positivist Mind Cast: The Garantismo Way, Res Publica, sv. 17, br. 4, $2011 .$, str. 327 - 342.

Gardašević, Đ., Neustavni ustavni amandmani i Ustavni sud Republike Hrvatske, u: Bačić, A. (ur.), Konstitucionalizacija demokratske politike, HAZU, Zagreb, 2014., str. $85-110$.

Guastini, R., La “costituzionalizzazione" dell'ordinamento italiano, Ragion pratica, sv. 11, 1998., str. $185-206$.

Guastini, R., Sintaksa prava, Naklada Breza, Zagreb, 2019.

Horvat Vuković, A., "U ime ustava" - materijalne granice promjene ustava, Zbornik Pravnog fakulteta u Zagrebu, sv. 65, br. 3-4, 2015., str. 488 - 494.

Kostadinov, B., Ustavni identitet, u: Bačić, A. (ur.), Dvadeseta obljetnica Ustava Republike Hrvatske, HAZU, Zagreb, 2011., str. 305 - 337.

Krešić, M., Legal consciousness and (de)constitutionalisation of the legal order, u: Mercescu, A. (ur.), Constitutional Identities in Central and Eastern Europe, Berlin, Peter Lang, 2020., str. 117 - 134.

Omejec, J., Veliki njemački ustav i nepromjenjiva ustavna načela u praksi Saveznog ustavnog suda, u: Zbornik "Pravo i pravda 2015" Pravnog fakulteta Univerziteta 
u Beogradu, u pripremi, dostupno na https://independent.academia.edu/ JasnaOmejec.

Padjen, I., Vjera u narod bez vlasti $i$ vlasništva (II.): Vlast naroda $i$ bezvlast puka, Anali Hrvatskog politološkog društva : časopis za politologiju, sv. 10, br. I, 2013., str. 197 - 219.

Smerdel, B., Ustavno uređenje europske Hrvatske, Narodne novine, Zagreb, 2013.

\section{Propisi:}

Ustav Republike Hrvatske, Narodne novine, br. 56/1990, 135/1997, 08/1998, 113/2000, 124/2000, 28/2001, 41/2001, 55/2001, 76/2010, 85/2010, 05/2014

Ustavni zakon o Ustavnom sudu Republike Hrvatske, Narodne novine, br. 99/1999, 29/2002, 49/2002

\section{Sudske odluke:}

Ustavni sud Republike Hrvatske

odluka broj: U-I-206/1992 od 8. prosinca 1993., dostupno na https://sljeme.usud. hr/usud/praksaw.nsf

odluka broj: U-I-231/1990 od 16. veljače 1994., dostupno na https://sljeme.usud. hr/usud/praksaw.nsf

odluka broj: U-I-28/1993 od 17. travnja 1994., dostupno na https://sljeme.usud. hr/usud/praksaw.nsf

odluka broj: U-I-348/1993 od 5. listopada 1994., dostupno na https://sljeme. usud.hr/usud/praksaw.nsf

odluka broj: U-I-46/1994 od 30. studenoga 1994., dostupno na https://sljeme. usud.hr/usud/praksaw.nsf

odluka broj: U-II-433/1994 i dr. od 2. veljače 1995., dostupno na https://sljeme. usud.hr/usud/praksaw.nsf

odluka broj: U-I-892/1994 od 20. studenoga 1996., dostupno na https://sljeme. usud.hr/usud/praksaw.nsf

odluka broj: U-I-697/1995 od 29. siječnja 1997., dostupno na https://sljeme.usud. hr/usud/praksaw.nsf

odluka broj: U-I-1037/1995 od 25. rujna 1997., dostupno na https://sljeme.usud. hr/usud/praksaw.nsf

odluka broj: U-I-20/1992 od 18. veljače 1998., dostupno na https://sljeme.usud. hr/usud/praksaw.nsf 
odluka broj: U-I-283/1997 od 12. svibnja 1998., dostupno na https://sljeme.usud. hr/usud/praksaw.nsf

odluka broj: U-I-920/1995 od 15. srpnja 1998., dostupno na https://sljeme.usud. hr/usud/praksaw.nsf

odluka broj: U-I-241/1998 od 31. ožujka 1999., dostupno na https://sljeme.usud. hr/usud/praksaw.nsf

odluka i rješenje broj: U-I-673/1996 i dr. od 21. travnja 1999., dostupno na https://sljeme.usud.hr/usud/praksaw.nsf

odluka broj: U-I-1156/1999, 26. siječnja 2000., dostupno na https://sljeme.usud. hr/usud/praksaw.nsf

odluka broj: U-I-902/1999 od 26. siječnja 2000., dostupno na https://sljeme. usud.hr/usud/praksaw.nsf

odluka broj: U-I-131/1998 od 3. veljače 2000., dostupno na https://sljeme.usud. hr/usud/praksaw.nsf

odluka broj: U-I-884/1997 od 3. veljače 2000., dostupno na https://sljeme.usud. hr/usud/praksaw.nsf

odluke i rješenja broj: U-I-659/1994 i dr. od 15. ožujka 2000., dostupno na https://sljeme.usud.hr/usud/praksaw.nsf

odluka broj: U-I-241/2000 od 10. svibnja 2000., dostupno na https://sljeme. usud.hr/usud/praksaw.nsf

odluka broj: U-I-646/1999 od 10. svibnja 2000., dostupno na https://ljeme. usud.hr/usud/praksaw.nsf

odluka broj: U-I-745/1999 od 8. studenoga 2000., dostupno na https://ljeme. usud.hr/usud/praksaw.nsf

odluka broj: U-I-607/1998 od 20. lipnja 2001., dostupno na https://sljeme.usud. $\mathrm{hr} / \mathrm{usud} /$ praksaw.nsf

rješenje broj: U-I-825/2001 od 14. siječnja 2004., dostupno na https://ljeme. usud.hr/usud/praksaw.nsf

odluka broj: U-I-2494/2002 od 24. ožujka 2004., dostupno na https://sljeme. usud.hr/usud/praksaw.nsf

odluka broj: U-I-3824/2003 od 28. travnja 2004., dostupno na https://ljeme. usud.hr/usud/praksaw.nsf

odluka broj: U-I-2510/2001 od 6. prosinca 2006., dostupno na https://sljeme. usud.hr/usud/praksaw.nsf

odluka broj: U-I-764/2004 i dr. od 21. ožujka 2007., dostupno na https://sljeme. usud.hr/usud/praksaw.nsf 
odluka broj: U-I-1152/2000 i dr. od 18. travnja 2007., dostupno na https://sljeme. usud.hr/usud/praksaw.nsf

odluka broj: U-I-205I/2007 od 5. lipnja 2007., dostupno na https://sljeme.usud. hr/usud/praksaw.nsf

odluka broj: U-I-4892/2004 od 12. ožujka 2008., dostupno na https://ljeme. usud.hr/usud/praksaw.nsf

odluka broj: U-I-3851/2004 od 12. ožujka 2008., dostupno na https://ljeme. usud.hr/usud/praksaw.nsf

odluka broj: U-IP-3820/2009 i U-IP-3826/2009 i dr. od 17. studenoga 2009., dostupno na https://sljeme.usud.hr/usud/praksaw.nsf

odluka broj: U-I-2771/2008 od 17. ožujka 2010., dostupno na https://sljeme. usud.hr/usud/praksaw.nsf

rješenja broj: U-I-1583/2000. i U-I-559/2001 od 24. ožujka 2010., Narodne novine, br. $46 / 2010$

odluka broj: U-III-3491/2006 i dr. od 7. srpnja 2010., dostupno na https://sljeme. usud.hr/usud/praksaw.nsf

odluka i rješenje broj: U-I-722/2009 od 6. travnja 2011., dostupno na https:// sljeme.usud.hr/usud/praksaw.nsf

odluka broj: U-I-295/2006 i U-I-4516/2007 od 6. srpnja 2011., dostupno na https://sljeme.usud.hr/usud/praksaw.nsf

odluka broj: U-I-3597/2010 i dr. od 29. srpnja 2011., dostupno na https://ljeme. usud.hr/usud/praksaw.nsf

odluka broj: U-I-5654/2011 od 15. veljače 2012., dostupno na https://ljeme. usud.hr/usud/praksaw.nsf

rješenje broj: U-I-6738/2010 od 11. lipnja 2013., dostupno na https://sljeme.usud. hr/usud/praksaw.nsf

priopćenje o narodnom ustavotvornom referendumu o definiciji braka, Sus1/2013 od 14. studenoga 2013., Narodne novine, br. 138/2013

odluka broj: U-I-4039/2009 i dr. od 18. srpnja 2014., dostupno na https://sljeme. usud.hr/usud/praksaw.nsf

odluka broj: U-I-5578/2013 i U-I-3633/2014 od 18. srpnja 2014., dostupno na https://sljeme.usud.hr/usud/praksaw.nsf

odluka broj: U-VIIR-4640/2014 od 12. kolovoza 2014., dostupno na https:// sljeme.usud.hr/usud/praksaw.nsf

rješenje broj: U-VIIR-4640/2014 od 15. listopada 2014., Narodne novine $130 / 2014$ 
odluka broj: U-VIIR-1159/2015 od 8. travnja 2015., Narodne novine, br. 43/2015 odluka broj: U-VIIR-1158/2015 od 21. travnja 2015., Narodne novine, br. 46/2015 odluka broj: U-III-4149/2014 od 24. srpnja 2015., Narodne novine, br. 89/2015 odluka broj: U-I-2036/2012 od 21. prosinca 2015., dostupno na https://sljeme. usud.hr/usud/praksaw.nsf

odluka broj: U-I-3676/2015 i dr. od 9. veljače 2016., dostupno na https://sljeme. usud.hr/usud/praksaw.nsf

odluka broj: U-I-354I/2015 od 4. svibnja 2016., dostupno na https://sljeme.usud. hr/usud/praksaw.nsf

odluka broj: U-I-2881/2014 i dr. od 1. lipnja 2016., Narodne novine, br. 55/2016 odluka broj: U-I-1962/2008 od 27. rujna 2016., dostupno na https://sljeme.usud. hr/usud/praksaw.nsf

rješenje broj: U-I-60/1991 i dr. od 21. veljače 2017., Narodne novine, br. 25/2017 odluka broj: U-I-65181-2009 od 13. lipnja 2017., dostupno na https://sljeme. usud.hr/usud/praksaw.nsf

rješenje broj: U-I-7883/2014 i dr. od 11. srpnja 2017., dostupno na https://sljeme. usud.hr/usud/praksaw.nsf

odluka broj: U-II-6111/2013 od 10. listopada 2017., dostupno na https://sljeme. usud.hr/usud/praksaw.nsf

odluka broj: U-I-3664/2015 i U-I-1007/2016 od 21. studenoga 2017., dostupno na https://sljeme.usud.hr/usud/praksaw.nsf

odluka broj: U-I-1574/2016 i U-I-1244/2017 od 30. siječnja 2018., dostupno na https://sljeme.usud.hr/usud/praksaw.nsf

rješenje broj: U-VIIR-3260/2018 od 18. prosinca 2018, dostupno na https://sljeme. usud.hr/usud/praksaw.nsf

odluka broj: U-I-2911/2017 od 5. veljače 2019., dostupno na https://sljeme.usud. hr/usud/praksaw.nsf

odluka broj: U-I-144/2019 i dr. od 29. siječnja 2020., dostupno na https://sljeme. usud.hr/usud/praksaw.nsf

odluka broj: U-I-2591/2019 od 24. lipnja 2020., dostupno na https://sljeme.usud. hr/usud/praksaw.nsf

odluka broj: U-I-1072/2019 od 7. srpnja 2020., dostupno na https://sljeme.usud. hr/usud/praksaw.nsf

odluka broj: U-I-4220/2020 od 20. listopada 2020., dostupno na https://ljeme. usud.hr/usud/praksaw.nsf 
Vrhovni sud Republike Hrvatske

presuda broj: Revr 1483/11-3 od 25. rujna 2012., dostupno na https:/sudskapraksa.csp.vsrh.hr/home

Županijski sud u Rijeci

presuda broj: Gž-2289/2017-2 od 13. ožujka 2019., dostupno na https://sudskapraksa.csp.vsrh.hr/home

Županijski sud u Zadru

presuda broj: 19 Gž-2452/14-2 od 19. travnja 2016., dostupno na https://sudskapraksa.csp.vsrh.hr/home

Upravni sud u Rijeci

presuda broj: 2 UsI-1594/15-15 od 29. lipnja 2016., dostupno na https://sudskapraksa.csp.vsrh.hr/home

presuda broj: 2 UsI-1298/2019-15 od 29. siječnja 2020, u posjedu autorâ presuda broj: 2 UsI-1293/2018-42 od 8. travnja 2020., u posjedu autorâ presuda broj: 2 UsI-100/2021-5 od 16. veljače 2021., u posjedu autorâ 


\section{Summary}

\section{Luka Burazin* \\ Đorđe Gardašević** \\ Mario Krešić****}

\section{CONSTITUTIONALIZATION OF THE CROATIAN LEGAL ORDER}

The paper describes the current stage of constitutionalization of the Croatian legal order by applying Guastini's model of constitutionalization, which consists of three necessary conditions and five aspects of constitutionalization. The first part of the paper establishes the fulfilment of the necessary conditions of constitutionalization of the Croatian legal order (long, rigid and judicially guaranteed constitution). The second part determines the indications of existence of aspects of constitutionalization of the Croatian legal order. First is examined the prevalence of the view that constitutional norms are legally binding. Thereafter the presence of the use of suprainterpretation of the constitution in the Croatian Constitutional Court's case-law is determined and the question of Croatian ordinary courts applying constitutional norms directly is addressed. Next, the use of accommodating interpretation in the Croatian Constitutional Court's case-law is addressed. Finally, the influence of the Croatian Constitution on the political relations in Croatia is assessed.

Keywords: constitutionalization; legal order; accommodating interpretation of laws; suprainterpretation of the constitution; direct application of constitutional norms

* Luka Burazin, Ph. D., Associate Professor, Faculty of Law, University of Zagreb, Trg Republike Hrvatske 14, 10000 Zagreb; lburazin@pravo.hr;

https://orcid.org/0000-0002-2437-8871

** Đorđe Gardašević, Ph. D., Associate Professor, Faculty of Law, University of Zagreb, Trg Republike Hrvatske 14, 10000 Zagreb; dorde.gardasevic@pravo.hr; https://orcid.org/0000-0002-2103-6139

*** Mario Krešić, Ph. D., Assistant Professor, Faculty of Law, University of Zagreb, Trg Republike Hrvatske 14, 10000 Zagreb; mario.kresic@pravo.hr, mariokresic3@ gmail.com;

https://orcid.org/0000-0002-0014-4157 